\title{
Carbon stock, chemical and physical properties of soils under management systems with different deployment times in western region of Paraná, Brazil ${ }^{1}$
}

\section{Estoque de carbono, propriedades químicas e físicas do solo em sistemas de manejo com diferentes tempos de implantação na Região Oeste do Paraná, Brasil}

\author{
Jean Sérgio Rosset ${ }^{2 *}$; Maria do Carmo Lana ${ }^{3}$; Marcos Gervasio Pereira \\ Jolimar Antonio Schiavo ${ }^{5}$, Leandro Rampim ${ }^{6}$; \\ Marcos Vinícius Mansano Sarto²; Edleusa Pereira Seidel ${ }^{7}$
}

\begin{abstract}
The objective of this study was evaluate the organic carbon stock and chemical and physical properties of soils in management systems with different deployment times under clayey Red Latosol in western region of Paraná, Brazil. Five managed areas and a reference area (native forest) without anthropic action were analyzed in completely randomized design with five repetitions. Management systems include three areas with different time of first adoption of no-till: 6 years - $\mathrm{NT}_{6}$ (transition phase), 14 years $-\mathrm{NT}_{14}$ (consolidation phase) and 22 years $-\mathrm{NT}_{22}$ (maintenance phase); 16 years of no-till, and in the last four years with integration of maize and ruzigrass (Brachiaria ruziziensis) $-(\mathrm{NT}+\mathrm{B})$ and an area of permanent and continuous extensive cattle pasture of coast-cross (Cynodon dactylon) - (Pa). Physical and chemical properties, total soil organic carbon (TOC) stock and carbon stratification index (SI) of soils were evaluated in depths of $0-0.05 ; 0.05-0.10 ; 0.10-0.20$ and $0.20-0.40 \mathrm{~m}$. The macroporosity (MA) was higher in the area of native forest, ranging from 0.23 to $0.30 \mathrm{~m}^{3} \mathrm{~m}^{-3}$ and the microporosity (MI) was higher in cultivated areas. The areas of NT+B and P presented lower ratio macroporosity/total pore volume (MA/TPV). For soil bulk density (BD) and soil penetration resistance (SPR), the managed areas show higher values, suggesting the occurrence of compacted subsurface layers. Native forest area showed the highest TOC levels in the depths of 0-0.05 and $0.05-0.10 \mathrm{~m}$, reaching $30.5 \mathrm{~g} \mathrm{~kg}^{-1}$ in the 0-0.05 $\mathrm{m}$ soil layer. There was negative change on TOC stocks in the managed areas in relation to forest area, being more evident in the more superficial soil layers. The SI was greater than one, however there is a reduction in function of adoption time of no-till. There was higher soil compaction in the managed areas, and the NT in soybean/maize succession system does not contribute effectively to the increase of TOC stocks.
\end{abstract}

Key words: No-till, carbon accumulation, crop succession

${ }^{1}$ Parte da Tese de Doutorado do primeiro autor, Universidade Estadual do Oeste do Paraná, UNIOESTE, Marechal Cândido Rondon, PR, Brasil.

${ }^{2}$ Discentes do Programa de Pós Graduação em Agronomia, PPGA, Centro de Ciências Agrárias, UNIOESTE, Marechal Cândido Rondon, PR, Brasil. E-mail: jsrosset@hotmail.com; marcos sarto@hotmail.com

${ }^{3}$ Prof ${ }^{a}$ Associada do Centro de Ciências Agrárias, CCA, UNIOESTE, Bolsista CNPq, Marechal Cândido Rondon, PR, Brasil. E-mail: maria.lana@unioeste.br

${ }^{4}$ Prof. Associado IV, Dept ${ }^{\mathrm{o}}$ de Solos, Universidade Federal Rural do Rio de Janeiro, UFRRJ, Bolsista do CNPq e Cientista do Nosso Estado da FAPERJ, Seropédica, RJ, Brasil. E-mail: gervasio@ufrrj.br

${ }^{5}$ Prof. Adjunto IV, Universidade Estadual de Mato Grosso do Sul, UEMS, Aquidauana, MS, Brasil. E-mail: schiavo@uems.br

${ }^{6}$ Pesquisador Científico CAPES/PNPD, Centro de Ciências Agrárias, UNIOESTE, Marechal Cândido Rondon, PR, Brasil. E-mail: rampimleandro@yahoo.com.br

${ }^{7}$ Prof ${ }^{a}$ do Centro de Ciências Agrárias, CCA/UNIOESTE, Marechal Cândido Rondon, PR, Brasil. E-mail: edleusa.seidel@ unioeste.br

* Author for correspondence 


\section{Resumo}

O objetivo do presente estudo foi avaliar os estoques de carbono, atributos químicos e físicos do solo em sistemas de manejo com diferentes tempos de implantação na região oeste do Paraná, Brasil. Foi utilizado o delineamento inteiramente casualizado com cinco repetições, e as áreas com diferentes tempos de adoção do sistema plantio direto (SPD) foram: 6 anos (fase de transição), 14 anos (fase de consolidação) e 22 anos (fase de manutenção); 16 anos de SPD, sendo nos últimos quatro anos com integração milho safrinha e Brachiaria; uma área de pastagem permanente coast-cross (Cynodon dactylon) e uma área de mata nativa. Os atributos químicos e físicos, o estoque de carbono e o índice de estratificação (IE) foram avaliados nas camadas de $0-0,05,0,05-0,1,0,1-0,2$ e 0,2-0,4 m. A macroporosidade (MA) foi superior na área de mata, variando de $0,23 \mathrm{a} 0,30 \mathrm{~m}^{3} \mathrm{~m}^{-3} \mathrm{e}$ a microporosidade (MI) foi superior nas áreas cultivadas. As áreas de SPD+B e pastagem apresentaram menor relação macroporos/volume total de poros (MA/VTP). Tanto para a densidade do solo (DS), quanto para a resistência à penetração (RP), as áreas manejadas apresentam valores superiores, o que sugere a ocorrência de camadas subsuperficiais compactadas. A área de mata apresentou teores de carbono orgânico total superiores nas camadas de 0-0,05 e 0,05-0,1 m, alcançando $30,5 \mathrm{~g} \mathrm{~kg}^{-1}$ na camada de $0-0,05 \mathrm{~m}$. Observa-se variação negativa nos estoque de carbono orgânico total nas áreas manejadas em relação à área de mata, sendo mais evidente nas camadas mais superficiais. O IE foi superior a um, porém verifica-se redução em função do tempo de adoção do SPD. Verifica-se maior compactação do solo nas áreas manejadas, e o SPD no sistema de sucessão soja/milho não contribui de forma efetiva para o aumento dos estoques de carbono orgânico do solo.

Palavras-chave: Sistema plantio direto, acúmulo de carbono, sucessão de culturas

\section{Introduction}

In tropical soils, soil organic matter (SOM) is one of the main properties responsible for the maintenance of its quality, and monitoring of the soil carbon levels can identify changes in the management systems adopted in relation to the quality and quantity of this organic fraction in cultivated soils (CARTER, 2002).

In agroecosystems, the amount of total soil organic carbon (TOC) stored results from the balance between inputs of carbon (C), mainly from crop residues, and $\mathrm{C}$ outputs from the SOM decomposition (ÁLVARO-FUENTES; EASTER; PAUSTIAN, 2012). Annual $\mathrm{C}$ accumulation may present high variability between regions, especially due to the diversity climate (tropical, subtropical and temperate climate), soil types, crop rotations and management practices adopted in relation to areas under natural vegetation (MARRIOTT; WANDER, 2006). Thus, the $\mathrm{C}$ level can remain stable, increase or decrease in relation to the natural system (FRAZÃO et al., 2010).

Adequate levels of SOM, besides maintaining the soil fertility, can minimize the impacts of agricultural practices on the environment due to C sequestration (BERNOUX et al., 1999). The adoption of soil management practices that minimize their disturbance may increase $\mathrm{C}$ inputs and reduce decomposition rates and carbon dioxide $\left(\mathrm{CO}_{2}\right)$ emissions into the atmosphere, consequently, increase TOC stocks (KRAGT et al., 2012) and, thus, are considered important soil management options to mitigate global warming (CERRI et al., 2011). Therefore, studies in different management systems are fundamental to the understanding of soil C dynamics (BERNOUX et al., 1999).

In addition to $\mathrm{C}$ stocks, the soil cultivation can change some physical properties such as soil bulk density (BD), total soil porosity (TSP) and pore distribution by size (BERTOL et al., 2004) compared to unimproved land. Some of these properties are associated with soil structural stability, as the BD (STONE; SILVEIRA, 2001), soil resistance to root penetration (RP) (BEUTLER; CENTURION, 2004) and TSP (OLIVEIRA et al., 2004), and these properties are used to assess the impacts of soil use and management on soil physical quality. In management systems of long-term without soil disturbance such as no-till (NT) and permanent 
pasture $(\mathrm{P})$, when not properly managed, the reduction of the macroporosity and increasing of BD has been detected (BERTOL et al., 2001).

The adoption of conservation cropping systems such as NT has increased considerably in the last decades (DIMASSI et al., 2013). Comparing areas of NT with 4, 8 and 12 years of implementation and an area in conventional tillage (12 years), Marcolan and Anghinoni (2006) found that after four years under NT, the soil had regained its original condition for physical properties: BD, macro- and microporosity and TSP. With respect to the soil chemical properties, the properly managed systems may promote increased TOC levels and stocks (PLAZA-BONILLA; CANTERO-MARTINEZ; ÁLVARO-FUENTES, 2010) and improve the phosphorus and exchangeable bases levels, especially in the superficial layers, over the course of time system deployment (DALCHIAVON et al., 2012). Furthermore, it has been reported significant relationships between adoption time of the NT and TOC stocks (UMAKANT; USSIRI; LAL, 2010).

One of the strategies used to evaluate the soil changes due to the use type and management techniques is the assessment of the chemical, physical and biological properties, comparing soils managed with those without management under natural vegetation (BARROS; COMERFORD, 2002). Thus, the present study investigated the changes in the organic carbon stock and chemical and physical properties of soils in management systems with different deployment times under clayey Red Latosol in western region of Paraná, Brazil.

\section{Material and Methods}

Soil samples were taken from commercial areas managed under different agricultural uses located in the Guaíra municipality, western region of the Paraná State, Brazil. The climate, according to Köppen classification is $\mathrm{Cfa}$, that is, a subtropical climate with relatively warm and wet summer (CAVIGLIONE et al., 2000). The mean rainfall is approximately $1500 \mathrm{~mm}$, the highest monthly mean temperature is over $28{ }^{\circ} \mathrm{C}$ and the lowest is below $18{ }^{\circ} \mathrm{C}$ (Figure 1). Rainfall, relative humidity, and temperature data during the period of 1973 and 2011 in the study region are shown in Figure 1. According to the detailed soil survey of the Paraná State (EMBRAPA, 2007), soils of the study areas are classified as clayey Rhodic Hapludox (Eutroferric Red Latosol in the Brazilian classification (EMBRAPA, 2013).

Five managed areas and a reference area (native forest) without anthropic action were evaluated, totaling six different management systems analyzed in completely randomized design with five repetitions (Figure 2). The five managed areas include three areas with different time of first adoption of no-till: 6 years - $\mathrm{NT}_{6}$ (transition phase), 14 years $-\mathrm{NT}_{14}$ (consolidation phase) and 22 years - $\mathrm{NT}_{22}$ (maintenance phase) (ANGHINONI, 2007); 16 years of no-till, and in the last four years with integration of maize and ruzigrass (Brachiaria ruziziensis) $(\mathrm{NT}+\mathrm{B})$ and an area of permanent and continuous extensive cattle pasture of coast-cross (Cynodon dactylon) (Pa). The stocking density of animals on pasture area is $3.5 \mathrm{AU} \mathrm{ha}^{-1}$. A detailed description of the study areas is shown in Table 1. 
Figure 1. Total monthly rainfall $(\mathrm{mm})$, relative air humidity $(\%)$, mean, maximum and minimum temperatures $\left({ }^{\circ} \mathrm{C}\right)$ during the period of 1973 to 2011 in the study region.

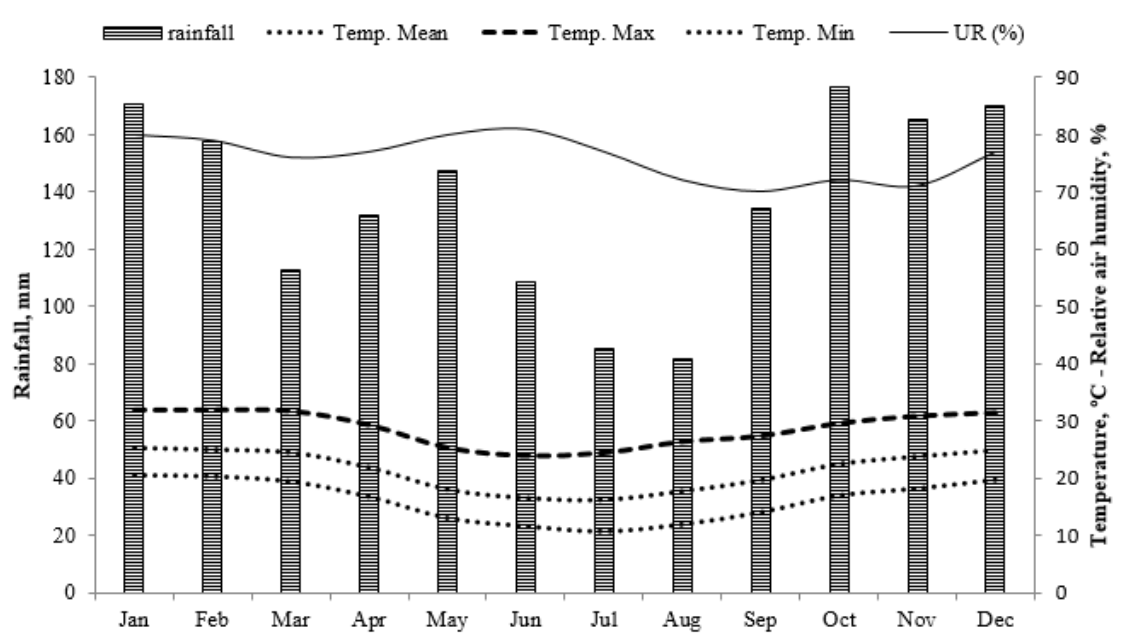

Source: Meteorological Station of the Agronomic Institute of Paraná - IAPAR (24\%18' S and $53^{\circ} 55^{\prime}$ W, Palotina, Paraná, Brazil).

Figure 2. Historic and changes of soil use in the experimental areas, with their dates of implementation in each system: CT: conventional tillage; NT: no-till; NT+B: no-till with integration of tropical grasses of the genus Brachiaria.

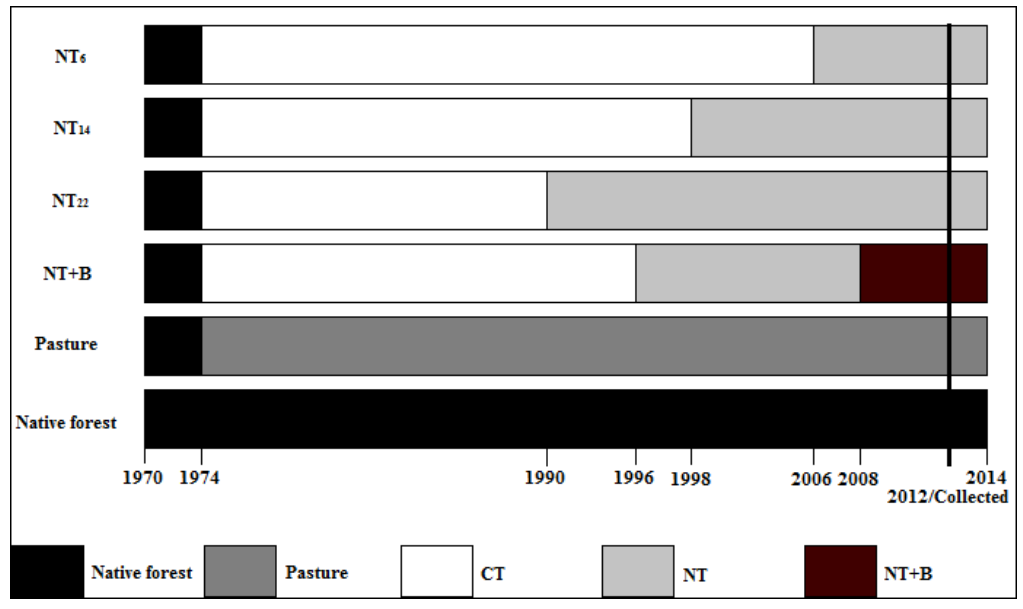

Source: Elaboration of the authors. 
Table 1. Historic and description of the experimental areas (management systems) studied under Rhodic Hapludox in the western region of Paraná State, 2012.

\begin{tabular}{|c|c|c|}
\hline Treatment & Management system & Description \\
\hline $\mathrm{NT}_{6}$ & No-till for 6 years & $\begin{array}{l}\text { Area situated at } 270 \mathrm{~m} \text { of altitude, located at } 24^{\circ} 09^{\prime} 092^{\prime} \mathrm{S} \text { and } 54^{\circ} 13^{\prime} 368^{\prime \prime} \mathrm{W} \text {. } \\
\text { No-till (6 years - transition phase). Total area of } 20 \text { hectares. }\end{array}$ \\
\hline $\mathrm{NT}_{14}$ & No-till for 14 years & $\begin{array}{l}\text { Area situated at } 298 \mathrm{~m} \text { of altitude, located at } 24^{\circ} 09^{\prime} 938^{\prime} \mathrm{S} \text { and } 54^{\circ} 14^{\prime} 190^{\prime \prime} \mathrm{W} \text {. } \\
\text { No-till (14 years - consolidation phase). Total area of } 17 \text { hectares. }\end{array}$ \\
\hline $\mathrm{NT}_{22}$ & No-till for 22 years & $\begin{array}{l}\text { Area situated at } 297 \mathrm{~m} \text { of altitude, located at } 24^{\circ} 15^{\prime} 454^{\prime} \text { S and } 54^{\circ} 10^{\prime} 361^{\prime \prime} \mathrm{W} \text {. } \\
\text { No-till (22 years - maintenance phase). Total area of } 77 \text { hectares. }\end{array}$ \\
\hline $\mathrm{NT}+\mathrm{B}$ & No-till + Brachiaria & $\begin{array}{l}\text { Area situated at } 281 \mathrm{~m} \text { of altitude, located at } 24^{\circ} 09^{\prime} 136^{\prime \prime} \mathrm{S} \text { and } 54^{\circ} 13^{\prime} 676^{\prime \prime} \\
\text { W. No-till with integration of maize + ruzigrass (Brachiaria ruziziensis). Total } \\
\text { area of } 20 \text { hectares. }\end{array}$ \\
\hline $\mathrm{Pa}$ & Pasture & $\begin{array}{l}\text { Area situated at } 302 \mathrm{~m} \text { of altitude, located at } 24^{\circ} 11^{\prime} 025^{\prime \prime} \mathrm{S} \text { and } 54^{\circ} 12^{\prime} 449^{\prime \prime} \mathrm{W} \text {. } \\
\text { Total area of } 2 \text { hectares. }\end{array}$ \\
\hline $\mathrm{F}$ & Native forest & $\begin{array}{l}\text { Area under native vegetation (Atlantic Forest - Seasonal semideciduous } \\
\text { forest) situated at } 295 \mathrm{~m} \text { of altitude, located at } 24^{\circ} 11^{\prime} 029^{\prime \prime} \mathrm{S} \text { and } 54^{\circ} 11^{\prime} 898^{\prime \prime} \\
\text { W used as a reference area. Total area of } 2 \text { hectares. }\end{array}$ \\
\hline
\end{tabular}

Source: Elaboration of the authors.

All areas after conversion of the conventional tillage system to no-till were cultivated with soybean (Glycine max L., Merrill) in the summer (October to February) followed by maize (Zea mays L.) or wheat (Triticum aestivum L.) in the fall-winter (March through July). Except for the integration area of maize and ruzigrass (Brachiaria ruziziensis), where ruzigrass was sown in the system with the purpose of increasing the production of straw for the cultivation of subsequent soybean. In all no-till areas with soybean and maize/wheat, the fertilization used in the last years of cultivation was carried out by applying $270 \mathrm{~kg} \mathrm{ha}^{-1} 02-20-18$ formulation at sowing and inoculation with Bradyrhizobium japonicum $(150 \mathrm{~mL}$ of inoculum for every $50 \mathrm{~kg}$ of seeds) and $270 \mathrm{~kg} \mathrm{ha}^{-1}$ of 10-15-15 formulation at sowing, respectively. Lime was applied every four years, at a rate of $1.7 \mathrm{Mg} \mathrm{ha}^{-1}$ with the exception of the no-till area for 14 years, that after the conversion of sowing system (conventional tillage to no-till in 1998), has not received practical correction of soil acidity. In the permanent pasture area were not performed correction or fertilization practices during the entire implementation period. In each study area was delimited five plots of $400 \mathrm{~m}^{2}$ for the collection of soil samples. Each plot represented a repetition or experimental unit.

For the determination of the soil physical properties, in each of the agricultural uses described above, 10 completely random disturbed soil samples per plot were collected from the $0-0.05 ; 0.05-0.10$; 0.10-0.20 and $0.20-0.40 \mathrm{~m}$ layer, to determine soil texture, water-dispersible clay (WDC), soil flocculation degree (FD), soil particle density (PD), as previously described by Embrapa (1997). Twenty completely random samples of undisturbed soil were also collected from the $0-0.05 ; 0.05-0.10 ; 0.10$ 0.20 and $0.20-0.40 \mathrm{~m}$ soil layer from each location, using a $46.2 \mathrm{~cm}^{3}$ cylindrical sampler, to determine soil bulk density (BD), macroporosity (MA) and microporosity (MI) by the tension table method (EMBRAPA, 1997), and total soil porosity (TSP) by summing the values for macro- and microporosity. From the data of the total porosity, the ratio macroporosity/total pore volume (MA/TPV) was calculated (TAYLOR; ASCHCROFT, 1972). Soil penetration resistance (SPR) and gravimetric soil water content (SWC) were quantified in saturated 
samples and after reaching equilibrium in tension table (field capacity), using a static penetrometer (model MA-933).

For the chemical analysis, soil also was sampled at depths of $0-0.05 ; 0.05-0.10 ; 0.10-0.20$ and 0.20 $0.40 \mathrm{~m}$ using a hole auger in ten different points per plot. Soil samples were air dried and ground to pass through a $2 \mathrm{~mm}$ mesh screen and analyzed. Soil $\mathrm{pH}$ in $0.01 \mathrm{~mol} \mathrm{~L}^{-1} \mathrm{CaCl}_{2}$ solution was determined potentiometrically in a 1:2.5 (soil:solution) suspension using a combined calomel reference glass electrode and $\mathrm{pH}$ meter. Aluminum (Al), calcium (Ca) and magnesium $(\mathrm{Mg})$ were extracted by $1 \mathrm{~mol}$ $\mathrm{L}^{-1} \mathrm{KCl}$ solution in a 1:10 (w:v) soil-to-extractant solution ratio and $\mathrm{Al}$ was determined by titration with $0.015 \mathrm{~mol} \mathrm{~L}^{-1} \mathrm{NaOH}$; $\mathrm{Ca}$ and $\mathrm{Mg}$ determined by atomic absorption spectrophotometry. Available phosphorus (P) and exchangeable potassium (K) were extracted by Mehlich-1 solution in a 1:10 $(\mathrm{w}: \mathrm{v})$ soil-to-extractant solution ratio and $\mathrm{P}$ was determined by colorimetry at $725 \mathrm{~nm}$ wave length and $\mathrm{K}$ was determined by flame photometry. Potential acidity $(\mathrm{H}+\mathrm{Al})$ was extracted by $0.5 \mathrm{~mol}$ $\mathrm{L}^{-1}$ calcium acetate solution buffered to $\mathrm{pH} 7.0$, and determined by titration with $0.1 \mathrm{~mol} \mathrm{~L}^{-1} \mathrm{NaOH}$. All chemical analyzes were performed by adopting standard procedures (EMBRAPA, 2009).

Organic carbon was quantified by oxidation with $0.167 \mathrm{~mol} \mathrm{~L}^{-1}$ potassium dichromate in the presence of sulfuric acid, followed by titration with $1.0 \mathrm{~mol} \mathrm{~L}^{-1}$ ammonium Fe(II)sulfate (EMBRAPA, 2009). From the results obtained, the total soil organic carbon (TOC) stocks were calculated by the equivalent mass method (ELLERT; BETTANY, 1995; SISTI et al., 2004). To verify the tendency of TOC accumulation or loss compared to the reference system (native forest), the change of TOC stock compared to the forest ( $\triangle \mathrm{TOC}, \mathrm{Mg} \mathrm{ha} \mathrm{cm}^{-1}$ ) was calculated by the difference between the mean values of TOC stock this system (reference) and in each other systems evaluated. The value obtained was then divided by the depth $(\mathrm{cm})$ of each layer.

With the TOC data, was also calculated the carbon stratification index (SI), which is based on the relation between the TOC levels in the surface layer compared to the lower layers. Values higher than one indicate $\mathrm{C}$ accumulation on the surface, and the most distant of the unit indicates that the better the soil quality. The existence of values less than one indicates that the system are losing quality (FRANZLUEBBERS, 2002).

In the winter season of 2012, after the maize harvest, the amount of accumulated crop residues on the soil surface was determined by taking samples from ten random points per plot, using a $0.25 \mathrm{~m}^{2}$ wooden frame. In the forested area leaves, small and thick branches were collected on the soil surface and in pasture area the grasses residues were collected. The collected plant material was ovendried at $60{ }^{\circ} \mathrm{C}$ for five days and then weighed.

Data were submitted to analysis of variance (ANOVA), and the results of different management systems were compared by Tukey test $(\mathrm{p}<0.05)$. As complementary analysis, multivariate technique was used by canonical analysis, involving all the variables studied (physical, chemical and carbon stock), from which was reduced data group in linear combinations, generating scores of the first two canonical variables that explain over $80 \%$ of the total variation (CROSS; REGAZZI, 1994), the score was projected in two-dimensional graphics. The grouping method of Tocher modified, with the purpose of discriminate the treatments with highest similarity, and for grouping the different management systems from the matrix of generalized Mahalanobis distance was also used. The graph based on canonical analysis and the groups formed by the grouping method of Tocher modified was generated using the Genes software for Windows (CRUZ, 2006). 


\section{Results and Discussion}

\section{Soil physical properties}

All study areas have clay content above $600 \mathrm{~g}$ $\mathrm{kg}^{-1}$, being classified as very clayey texture (Table 2). Data of water-dispersible clay (WDC) and soil flocculation degree (FD) infer the degree of soil aggregation (EMBRAPA, 1997), and the highest values of $F D$ in the $0-0.05 \mathrm{~m}$ soil layer were observed in the pastures and native forest areas, 85 and $86 \%$, respectively, differing of $\mathrm{NT}_{6}$ and $\mathrm{NT}+\mathrm{B}$ areas (Table 2). The $\mathrm{NT}_{14}$ and $\mathrm{NT}_{22}$ areas had presented similar WDC values to native forest, except in the $0-0.05 \mathrm{~m}$ layer to the area under $\mathrm{NT}_{14}$. In all management systems and layers, the values of soil particle density (PD) ranged from 2.72 to $2.84 \mathrm{~g}$ $\mathrm{cm}^{-3}$, similar to those values reported by Lourente et al. (2011) in a Distroferric Red Latosol. The lower values for PD, especially in the first two layers, in the forested area was due to higher levels of soil organic matter (SOM). One factor that contributes to the reduction of the PD is the SOM content (BRADY; BUCKMAN, 1983).

For macroporosity (MA) were observed in all layers, higher values in the forested area, ranging from 0.23 to $0.30 \mathrm{~m}^{3} \mathrm{~m}^{-3}$, except for the $\mathrm{NT}_{6}$ area in the $0-0.05 \mathrm{~m}$ soil layer, that showed similar values to the forest area (Table 3). There was tendency of reduction in the MA in depth, especially in areas managed under NT, with values of $0.08 \mathrm{~m}^{3} \mathrm{~m}^{-3}$ in the $0.10-0.20 \mathrm{~m}$ soil layer in the $\mathrm{NT}_{6}$ system. Similar results were reported by Torres, Fabian and Pereira (2011) in areas of NT and permanent pasture, compared with the natural vegetation.

Table 2. Particle size analysis, water-dispersible clay (WDC), soil flocculation degree (FD) and particle density (PD) of soils under management systems with different deployment times in the western region of Paraná, Brazil, in 2012.

\begin{tabular}{|c|c|c|c|c|c|c|}
\hline \multirow{3}{*}{$\begin{array}{c}\text { Management } \\
\text { system }\end{array}$} & Sand & Silt & Clay & WDC & FD & PD \\
\hline & \multicolumn{4}{|c|}{--------------------g kg-1------------------- } & $\%$ & $\mathrm{~g} \mathrm{~cm}^{-3}$ \\
\hline & \multicolumn{6}{|c|}{$0-0,05 \mathrm{~m}$} \\
\hline $\mathrm{NT}_{6}$ & 170 & 216 & 614 & $152 \mathrm{a}$ & $75 b$ & 2.77 \\
\hline $\mathrm{NT}_{14}$ & 145 & 186 & 669 & $152 \mathrm{a}$ & $77 \mathrm{ab}$ & 2.75 \\
\hline $\mathrm{NT}_{22}$ & 101 & 276 & 623 & $102 \mathrm{abc}$ & $84 \mathrm{ab}$ & 2.77 \\
\hline $\mathrm{NT}+\mathrm{B}$ & 173 & 209 & 618 & $146 \mathrm{ab}$ & $76 b$ & 2.80 \\
\hline Pasture & 86 & 292 & 623 & $90 \mathrm{bc}$ & $85 a$ & 2.79 \\
\hline Native forest & 118 & 265 & 617 & $86 c$ & $86 a$ & 2.72 \\
\hline \multirow[t]{2}{*}{$\mathrm{CV}(\%)$} & & & & 23.6 & 5.7 & \\
\hline & \multicolumn{6}{|c|}{$0,05-0,1 \mathrm{~m}$} \\
\hline $\mathrm{NT}_{6}$ & 167 & 220 & 613 & $152 a$ & $75 a$ & 2.79 \\
\hline $\mathrm{NT}_{14}^{0}$ & 145 & 157 & 698 & $164 a$ & $76 a$ & 2.78 \\
\hline $\mathrm{NT}_{22}$ & 101 & 271 & 628 & $120 \mathrm{a}$ & $81 \mathrm{a}$ & 2.79 \\
\hline $\mathrm{NT}+\mathrm{B}$ & 170 & 210 & 619 & $151 \mathrm{a}$ & $76 a$ & 2.82 \\
\hline Pasture & 87 & 293 & 620 & $142 a$ & $77 \mathrm{a}$ & 2.80 \\
\hline Native forest & 125 & 256 & 620 & $112 a$ & $82 a$ & 2.74 \\
\hline \multirow[t]{2}{*}{$\mathrm{CV}(\%)$} & & & & 23.2 & 6.8 & \\
\hline & \multicolumn{6}{|c|}{$0,1-0,2 \mathrm{~m}$} \\
\hline $\mathrm{NT}_{6}$ & 142 & 202 & 657 & $191 \mathrm{a}$ & $71 b$ & 2.81 \\
\hline $\mathrm{NT}_{14}$ & 126 & 150 & 724 & $169 a b c$ & $77 \mathrm{ab}$ & 2.82 \\
\hline $\mathrm{NT}_{22}$ & 92 & 267 & 641 & $131 b c$ & $80 \mathrm{a}$ & 2.80 \\
\hline $\mathrm{NT}+\mathrm{B}$ & 157 & 218 & 626 & $185 \mathrm{ab}$ & $71 \mathrm{~b}$ & 2.84 \\
\hline Pasture & 86 & 300 & 614 & $153 \mathrm{abc}$ & $75 \mathrm{ab}$ & 2.83 \\
\hline Native forest & 104 & 282 & 614 & $123 c$ & $80 a$ & 2.76 \\
\hline CV(\%) & & & & 18.7 & 5.4 & \\
\hline
\end{tabular}


continuação

\begin{tabular}{|c|c|c|c|c|c|c|}
\hline \multirow[b]{2}{*}{$\mathrm{NT}_{6}$} & \multicolumn{6}{|c|}{$0,2-0,4 \mathrm{~m}$} \\
\hline & 124 & 209 & 667 & $163 b$ & $76 a$ & 2.82 \\
\hline $\mathrm{NT}_{14}$ & 104 & 141 & 755 & $183 \mathrm{ab}$ & $76 a$ & 2.84 \\
\hline $\mathrm{NT}_{22}^{14}$ & 81 & 256 & 663 & $145 b$ & $78 \mathrm{a}$ & 2.82 \\
\hline $\mathrm{NT}+\mathrm{B}$ & 129 & 227 & 645 & $186 a b$ & $71 \mathrm{ab}$ & 2.84 \\
\hline Pasture & 74 & 227 & 700 & $228 \mathrm{a}$ & $68 b$ & 2.84 \\
\hline Native forest & 97 & 196 & 707 & $161 b$ & $77 \mathrm{a}$ & 2.80 \\
\hline CV $(\%)$ & & & & 16.1 & 4.9 & \\
\hline
\end{tabular}

Values represented by the different letters in the column, for each soil depth show significant differences (Tukey test, $\mathrm{P} \leq 0.05$ ). Source: Elaboration of the authors.

Although no differences in the $0-0.05 \mathrm{~m}$ soil layer has been found in areas under $\mathrm{NT}_{14}$ and $\mathrm{NT}_{22}$, there was a tendency of reduction in the MA as a function of implantation time of NT. The same was observed for MI values, particularly in the 0-0.05 and $0.05-0.10 \mathrm{~m}$ soil layer, as well as are higher than the values of the native forest area. According to Viana et al. (2011), the drastic reduction of the MA in cultivated soils is due to the greater amount of compression by the intensive traffic of agricultural machinery. This tendency was also observed for total soil porosity (TSP), where there were no differences in the 0-0.05 $\mathrm{m}$ layer in the evaluated areas. For the other layers, the highest values were observed in the forested area, not differing of the pasture areas in the first three layers, and $\mathrm{NT}+\mathrm{B}$ in the last layer evaluated.

Table 3. Porosity, bulk density (BD), ratio macroporosity/total pore volume (MA/TPV) penetration resistance (SPR) e water content (SWC) of soils under management systems with different deployment times in the western region of Paraná, Brazil, in 2012.

\begin{tabular}{|c|c|c|c|c|c|c|c|c|c|}
\hline \multirow[t]{2}{*}{$\begin{array}{l}\text { Management } \\
\text { system }\end{array}$} & \multicolumn{3}{|c|}{$\begin{array}{l}\text { Soil porosity } \\
\qquad\left(\mathrm{m}^{3} \mathrm{~m}^{-3}\right)\end{array}$} & \multirow[t]{2}{*}{$\begin{array}{c}\text { Ratio } \\
\text { MA/TPV }\end{array}$} & \multirow{2}{*}{$\begin{array}{c}\begin{array}{c}\text { Bulk } \\
\text { density } \\
\left(\mathrm{Mg} \mathrm{m}^{-3}\right)\end{array} \\
0-0.05 \mathrm{~m}\end{array}$} & \multicolumn{2}{|c|}{$\begin{array}{l}\text { Penetration } \\
\text { resistance }(\mathrm{MPa})\end{array}$} & \multicolumn{2}{|c|}{$\begin{array}{l}\text { Water content } \\
\theta\left(\mathrm{cm}^{3} \mathrm{~cm}^{-3}\right)\end{array}$} \\
\hline & Macro & Micro & Total & & & $\mathrm{Rp}_{\mathrm{S}}$ & $\mathrm{Rp}_{24}$ & $\mathrm{UM}_{\mathrm{s}}$ & $\mathrm{UM}_{24}$ \\
\hline $\mathrm{NT}_{6}$ & $0.23 \mathrm{ab}$ & $0.36 \mathrm{~b}$ & $0.59 \mathrm{a}$ & 0.39 & $1.22 \mathrm{a}$ & $0.34 \mathrm{c}$ & $0.79 b$ & $0.57 \mathrm{a}$ & $0.36 \mathrm{~b}$ \\
\hline $\mathrm{NT}_{14}$ & $0.20 \mathrm{bc}$ & $0.39 \mathrm{ab}$ & $0.59 \mathrm{a}$ & 0.34 & $1.21 \mathrm{a}$ & $0.41 b c$ & $0.69 \mathrm{~b}$ & $0.57 \mathrm{a}$ & $0.39 \mathrm{ab}$ \\
\hline $\mathrm{NT}_{22}$ & $0.19 b c$ & $0.40 \mathrm{ab}$ & $0.59 \mathrm{a}$ & 0.32 & $1.15 \mathrm{a}$ & $0.60 \mathrm{~b}$ & $0.82 \mathrm{~b}$ & $0.58 \mathrm{a}$ & $0.40 \mathrm{ab}$ \\
\hline $\mathrm{NT}+\mathrm{B}$ & $0.14 b c$ & $0.37 \mathrm{ab}$ & $0.51 \mathrm{a}$ & 0.27 & $1.30 \mathrm{a}$ & $1.25 \mathrm{a}$ & $1.63 \mathrm{a}$ & $0.49 a$ & $0.37 \mathrm{ab}$ \\
\hline Pasture & $0.14 \mathrm{c}$ & $0.42 \mathrm{a}$ & $0.56 \mathrm{a}$ & 0.25 & $1.15 \mathrm{a}$ & $1.34 \mathrm{a}$ & $1.53 \mathrm{a}$ & $0.54 \mathrm{a}$ & $0.43 \mathrm{a}$ \\
\hline Native forest & $0.30 \mathrm{a}$ & $0.27 \mathrm{c}$ & $0.57 \mathrm{a}$ & 0.52 & $0.80 \mathrm{~b}$ & $0.08 \mathrm{~d}$ & $0.29 \mathrm{c}$ & $0.56 \mathrm{a}$ & $0.27 \mathrm{c}$ \\
\hline CV (\%) & 23.6 & 8.3 & 7.6 & & $\begin{array}{l}8.3 \\
0.05-0.1 \mathrm{~m}\end{array}$ & 14.6 & 8.5 & 7.9 & 8.4 \\
\hline $\mathrm{NT}_{6}$ & $0.12 b$ & $0.39 \mathrm{a}$ & $0.51 b c$ & 0.23 & $1.46 \mathrm{a}$ & $0.88 \mathrm{~b}$ & $1.51 \mathrm{~cd}$ & $0.50 \mathrm{~b}$ & $0.39 \mathrm{a}$ \\
\hline $\mathrm{NT}_{14}$ & $0.13 b$ & $0.39 \mathrm{ab}$ & $0.52 b c$ & 0.25 & $1.42 \mathrm{a}$ & $1.10 \mathrm{~b}$ & $1.30 \mathrm{~d}$ & $0.50 \mathrm{~b}$ & $0.38 \mathrm{ab}$ \\
\hline $\mathrm{NT}_{22}$ & $0.09 \mathrm{~b}$ & $0.41 \mathrm{a}$ & $0.50 \mathrm{c}$ & 0.18 & $1.37 \mathrm{ab}$ & $1.78 \mathrm{a}$ & $2.09 a$ & $0.49 b$ & $0.41 \mathrm{a}$ \\
\hline $\mathrm{NT}+\mathrm{B}$ & $0.1 b$ & $0.41 \mathrm{a}$ & $0.51 b c$ & 0.20 & $1.46 \mathrm{a}$ & $1.51 \mathrm{a}$ & $1.79 b$ & $0.50 \mathrm{~b}$ & $0.41 \mathrm{a}$ \\
\hline Pasture & $0.15 b$ & $0.41 \mathrm{a}$ & $0.56 \mathrm{ab}$ & 0.27 & $1.20 \mathrm{~b}$ & $0.84 b$ & $1.58 \mathrm{bc}$ & $0.54 \mathrm{ab}$ & $0.41 \mathrm{a}$ \\
\hline Native forest & $0.26 \mathrm{a}$ & $0.33 b$ & $0.59 \mathrm{a}$ & 0.44 & $0.99 \mathrm{c}$ & $0.25 \mathrm{c}$ & $0.64 \mathrm{e}$ & $0.57 \mathrm{a}$ & $0.33 b$ \\
\hline CV (\%) & 29.6 & 7.6 & 5.2 & & 8.1 & 15.8 & 9.2 & 5.6 & 7.7 \\
\hline
\end{tabular}


continuação

\begin{tabular}{|c|c|c|c|c|c|c|c|c|c|}
\hline $\mathrm{NT}_{6}$ & $0.08 \mathrm{c}$ & $0.41 \mathrm{a}$ & $0.49 \mathrm{c}$ & 0.16 & $\begin{array}{l}0.1-0.2 \mathrm{~m} \\
1.53 \mathrm{a}\end{array}$ & $1.39 \mathrm{~b}$ & $1.53 \mathrm{~b}$ & $0.48 \mathrm{c}$ & $0.41 \mathrm{a}$ \\
\hline $\mathrm{NT}_{14}$ & $0.12 b c$ & $0.40 \mathrm{a}$ & $0.52 b c$ & 0.23 & $1.38 \mathrm{~b}$ & $1.09 \mathrm{c}$ & $1.31 \mathrm{~b}$ & $0.51 b c$ & $0.40 \mathrm{a}$ \\
\hline $\mathrm{NT}_{22}^{14}$ & $0.09 \mathrm{bc}$ & $0.40 \mathrm{a}$ & $0.49 \mathrm{c}$ & 0.18 & $1.37 \mathrm{~b}$ & $1.61 \mathrm{a}$ & $1.82 \mathrm{a}$ & $0.48 \mathrm{c}$ & $0.40 \mathrm{a}$ \\
\hline $\mathrm{NT}+\mathrm{B}$ & $0.09 \mathrm{bc}$ & $0.41 \mathrm{a}$ & $0.50 \mathrm{c}$ & 0.18 & $1.47 \mathrm{ab}$ & $1.62 \mathrm{a}$ & $1.91 \mathrm{a}$ & $0.49 \mathrm{c}$ & $0.41 \mathrm{a}$ \\
\hline Pasture & $0.15 b$ & $0.39 \mathrm{a}$ & $0.54 \mathrm{ab}$ & 0.28 & $1.23 \mathrm{c}$ & $0.97 \mathrm{c}$ & $1.50 \mathrm{~b}$ & $0.53 \mathrm{ab}$ & $0.40 \mathrm{a}$ \\
\hline Native forest & $0.25 \mathrm{a}$ & $0.33 b$ & $0.58 \mathrm{a}$ & 0.43 & $1.11 \mathrm{c}$ & $0.30 \mathrm{~d}$ & $0.89 \mathrm{c}$ & $0.56 \mathrm{a}$ & $0.33 b$ \\
\hline CV (\%) & 22.7 & 5.7 & 3.7 & & $\begin{array}{l}4.8 \\
0.2-0.4 \mathrm{~m}\end{array}$ & 10.1 & 9.8 & 3.8 & 5.5 \\
\hline $\mathrm{NT}_{6}$ & $0.09 \mathrm{~b}$ & $0.44 \mathrm{a}$ & $0.53 b$ & 0.17 & $1.44 \mathrm{a}$ & $0.96 \mathrm{~b}$ & $1.13 \mathrm{~b}$ & $0.52 \mathrm{a}$ & $0.45 \mathrm{a}$ \\
\hline $\mathrm{NT}_{14}$ & $0.12 b$ & $0.41 \mathrm{ab}$ & $0.53 b$ & 0.23 & $1.37 \mathrm{ab}$ & $0.89 \mathrm{bc}$ & $1.24 \mathrm{~b}$ & $0.52 \mathrm{a}$ & $0.41 \mathrm{ab}$ \\
\hline $\mathrm{NT}_{22}$ & $0.11 b$ & $0.41 \mathrm{ab}$ & $0.52 b$ & 0.21 & $1.28 \mathrm{bc}$ & $0.77 \mathrm{~cd}$ & $1.08 \mathrm{~b}$ & $0.51 \mathrm{a}$ & $0.42 \mathrm{ab}$ \\
\hline $\mathrm{NT}+\mathrm{B}$ & $0.11 b$ & $0.43 \mathrm{ab}$ & $0.54 \mathrm{ab}$ & 0.20 & $1.49 \mathrm{a}$ & $1.46 \mathrm{a}$ & $1.63 \mathrm{a}$ & $0.53 \mathrm{a}$ & $0.43 \mathrm{ab}$ \\
\hline Pasture & $0.13 b$ & $0.40 \mathrm{~b}$ & $0.53 b$ & 0.24 & $1.23 b c$ & $0.69 \mathrm{~d}$ & $1.21 \mathrm{~b}$ & $0.51 \mathrm{a}$ & $0.40 \mathrm{~b}$ \\
\hline Native forest & $0.23 a$ & $0.33 \mathrm{c}$ & $0.56 \mathrm{a}$ & 0.41 & $1.12 \mathrm{c}$ & $0.26 \mathrm{e}$ & $0.75 \mathrm{c}$ & $0.53 a$ & $0.33 c$ \\
\hline CV (\%) & 16.3 & 5.8 & 3.0 & & 6.3 & 9.9 & 7.4 & 5.5 & 5.9 \\
\hline
\end{tabular}

Values represented by the different letters in the column, for each soil depth show significant differences (Tukey test, $\mathrm{P} \leq 0.05$ ). $\mathrm{SPRs}_{\mathrm{SPR}}$ : Soil penetration resistance in saturated samples and after reaching equilibrium ( $\left.24 \mathrm{hs}\right)$ in tension table, respectively. $\mathrm{SWCs}$ and $\mathrm{SWC}_{24}$ : Soil water content in saturated samples and after reaching equilibrium (24 hs) in tension table, respectively. Source: Elaboration of the authors.

In all layers, the areas under $\mathrm{NT}+\mathrm{B}$ and pasture presented values of the ratio macroporosity/ total pore volume (MA/TPV) less than $0.33 \mathrm{~m}^{3}$ $\mathrm{m}^{-3}$, minimum value, considered ideal for crop development (TORRES; FABIAN; PEREIRA, 2011). For the different adoption times of no-till the lowest values were observed in the subsurface soil layers, reaching $0.18 \mathrm{~m}^{3} \mathrm{~m}^{-3}$ for the $\mathrm{NT}_{22}$ in the 0.05 0.10 and $0.10-0.20 \mathrm{~m}$ layers, and 0.16 and $0.17 \mathrm{~m}^{3}$ $\mathrm{m}^{-3}$ for the $\mathrm{NT}_{6}$ in the $0.10-0.20 \mathrm{~m}$ and $0.20-0.40 \mathrm{~m}$ soil layers, respectively. This standard differs from the reported forest area, where the values of this ratio ranged from 0.41 to $0.52 \mathrm{~m}^{3} \mathrm{~m}^{-3}$. In turn, in the 0-0.05 m layer, with the macropores reduction and micropores elevation due to the greater adoption time of NT there was decrease the ratio MA/TPV.

For the soil bulk density (BD), the forest area showed lower values, differing from five managed areas, especially in the first two layers, reaching $0.80 \mathrm{Mg} \mathrm{m}^{-3}$ in the $0-0.05 \mathrm{~m}$ layer. This result is due to the absence of any type of soil management or animal grazing in this area, and because the existing vegetation provides high presence of roots. In general, there was increase in the BD of managed areas, especially in the subsurface layers, reaching $1.53 \mathrm{Mg} \mathrm{m}^{-3}$ for the $0.10-0.20 \mathrm{~m}$ layer in the $\mathrm{NT}_{6}$ system. Viana et al. (2011) in cultivated areas compared to native forest reported similar results. Dimassi et al. (2013) in long-term experiment (20 years) under NT, found values of $1.50 \mathrm{Mg} \mathrm{m}^{-3}$ in the $0.10-0.20 \mathrm{~m}$ soil layer. These values are close to the values considered critical $\left(1.60 \mathrm{Mg} \mathrm{m}^{-3}\right)$ for crop development (SILVA; ROSOLEM, 2001).

There was increase of soil penetration resistance (SPR) with decreasing the soil water content (SWC). In the layers of 0.05-0.10 and 0.10-0.20 m, the highest SPR values, from 1.78 to $1.62 \mathrm{MPa}$ for the saturated samples and from 2.09 and $1.91 \mathrm{MPa}$ for the samples in field capacity were observed in the $\mathrm{NT}_{22}$ and $\mathrm{NT}+\mathrm{B}$, respectively. In all soil profile, the managed areas differed from the forest area in relation the SPR values. The high values found in managed areas may be related to traffic machines on condition of high soil moisture (MARCOLAN; ANGHINONI, 2006), being aggravated by the high clay content of the studied sites (Table 3 ). Soil 
penetration resistance values above $2.0 \mathrm{MPa}$ are considered limiting to the root growth of the plants (TORMENA; ROLOFF; SÁ, 1998).

The values of density and resistance obtained indicate the presence of compacted layers in the subsurface, which may limit the root growth of plants cultivated in succession systems, and, consequently restrict crop yields, especially in times of drought stress, mainly by reducing the soil volume explored by the root system of plants. In such cases, the minimum soil disturbance with chisel plow in certain period of the NT (QUINCKE et al., 2007) has reduced soil compaction in the subsoil, between 0.15 to $0.25 \mathrm{~m}$, as reported in the study of Ferreras et al. (2000). Dimassi et al. (2013) observed density values greater than $4 \%$ in areas that were not receive annual chiseling in relation the chiseled areas.

\section{Soil chemical properties}

The results of the soil chemical properties of the different areas studied are presented in Table 4. In general, the highest values of soil $\mathrm{pH}$ were observed in native forested and pasture areas, differing from the other areas in the 0.05-0.10 and 0.10-0.20 m layers. This standard differed from that observed for the $\mathrm{NT}_{14}$ area, which had lower values than the other areas. This fact is related to the absence of soil acidity correction after the implantation of no-till in 1998. Soil acidification is a continuous process that persists even after liming, since the decomposition of organic matter added $\mathrm{H}^{+}$ions to the soil, as well as the ion exchange that occurs between the plant roots and the soil colloids. In this process, the plants absorb for example $\mathrm{K}^{+}, \mathrm{Ca}^{2+}$ and $\mathrm{Mg}^{2+}$ ions, releasing $\mathrm{H}^{+}$ions, increasing the soil acidity with the with successive crops (BARBOSA FILHO; FAGERIA; ZIMMERMANN, 2005). These low $\mathrm{pH}$ values in the soil under $\mathrm{NT}_{14}$, justify the higher values of potential acidity $(\mathrm{H}+\mathrm{Al})$ in all evaluated layers, reaching the value of $5.4 \mathrm{cmol}_{\mathrm{c}} \mathrm{dm}^{-3}$ in the 0.05 $0.10 \mathrm{~m}$ soil layer. Similar results were observed for the $\mathrm{Al}^{3+}$ levels, which was higher only in the area of $\mathrm{NT}_{14}$, ranging from 0.10 to $0.50 \mathrm{cmol}_{\mathrm{c}} \mathrm{dm}^{-3}$.

Table 4. Soil $\mathrm{pH}\left(\mathrm{CaCl}_{2}\right)$, phosphorus $(\mathrm{P})$, potential acidity $(\mathrm{H}+\mathrm{Al})$, aluminum (Al), calcium (Ca), magnesium $(\mathrm{Mg})$, potassium (K), total soil organic carbon (TOC), and TOC stock of soils under management systems with different deployment times in the western region of Paraná, Brazil, in 2012.

\begin{tabular}{|c|c|c|c|c|c|c|c|c|c|}
\hline $\begin{array}{l}\text { Management } \\
\text { system }\end{array}$ & $\mathrm{pH}$ & $\mathrm{P}$ & $\mathrm{H}+\mathrm{Al}$ & $\mathrm{Al}$ & $\mathrm{Ca}$ & $\mathrm{Mg}$ & K & TOC & $\begin{array}{l}\text { TOC } \\
\text { stock }\end{array}$ \\
\hline & \multicolumn{7}{|c|}{ 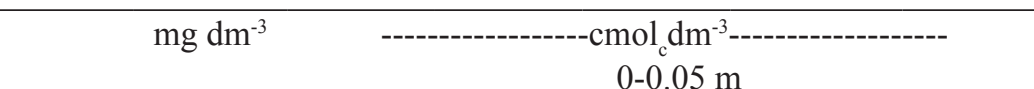 } & $\mathrm{g} \mathrm{kg}^{-1}$ & $\mathrm{Mg} \mathrm{ha}^{-1}$ \\
\hline $\mathrm{NT}_{6}$ & $5.8 b$ & $13.4 b$ & $2.9 \mathrm{~b}$ & $0.0 \mathrm{~b}$ & $5.5 \mathrm{~b}$ & $1.8 \mathrm{a}$ & $0.5 \mathrm{ab}$ & $12.1 \mathrm{c}$ & $5.0 \mathrm{c}$ \\
\hline $\mathrm{NT}_{14}^{6}$ & $5.1 \mathrm{c}$ & $14.9 \mathrm{~b}$ & $4.3 \mathrm{a}$ & $0.1 \mathrm{a}$ & $3.1 \mathrm{c}$ & $1.0 \mathrm{~b}$ & $0.3 b c$ & $12.4 \mathrm{c}$ & $5.1 \mathrm{c}$ \\
\hline $\mathrm{NT}_{22}$ & $6.0 \mathrm{ab}$ & $21.8 \mathrm{a}$ & $3.2 b$ & $0.0 \mathrm{~b}$ & $6.3 b$ & $1.3 \mathrm{ab}$ & $0.6 \mathrm{a}$ & $15.6 \mathrm{bc}$ & $6.4 \mathrm{bc}$ \\
\hline $\mathrm{NT}+\mathrm{B}$ & $6.0 \mathrm{ab}$ & $26.6 \mathrm{a}$ & $2.6 \mathrm{~b}$ & $0.0 \mathrm{~b}$ & $5.6 \mathrm{~b}$ & $1.1 \mathrm{~b}$ & $0.5 \mathrm{ab}$ & $12.5 \mathrm{c}$ & $5.2 \mathrm{c}$ \\
\hline Pasture & $6.2 \mathrm{ab}$ & $10.7 \mathrm{~b}$ & $3.2 b$ & $0.0 \mathrm{~b}$ & $2.9 \mathrm{c}$ & $1.0 \mathrm{~b}$ & $0.3 \mathrm{c}$ & $19.0 \mathrm{~b}$ & $7.9 b$ \\
\hline Native forest & $6.4 \mathrm{a}$ & $9.7 \mathrm{~b}$ & $2.7 \mathrm{~b}$ & $0.0 \mathrm{~b}$ & $8.6 a$ & $1.0 \mathrm{~b}$ & $0.4 b c$ & $30.5 \mathrm{a}$ & $12.5 \mathrm{a}$ \\
\hline \multirow[t]{2}{*}{$\mathrm{CV}(\%)$} & 3.7 & 16.9 & 17.8 & 25.2 & 17.5 & 31.5 & 21.8 & 13.9 & 14.6 \\
\hline & \multicolumn{9}{|c|}{$0.05-0.1 \mathrm{~m}$} \\
\hline $\mathrm{NT}_{6}$ & $5.5 b$ & $22.3 b c$ & $3.7 \mathrm{bc}$ & $0.0 \mathrm{~b}$ & $4.2 \mathrm{bc}$ & $1.2 \mathrm{a}$ & $0.3 \mathrm{abc}$ & $7.8 \mathrm{c}$ & $4.4 \mathrm{c}$ \\
\hline $\mathrm{NT}_{14}^{6}$ & $4.8 \mathrm{c}$ & $38.5 \mathrm{a}$ & $5.4 \mathrm{a}$ & $0.5 \mathrm{a}$ & $2.2 \mathrm{c}$ & $0.6 \mathrm{~b}$ & $0.2 b c$ & $8.5 \mathrm{c}$ & $5.1 \mathrm{bc}$ \\
\hline $\mathrm{NT}_{22}^{14}$ & $5.5 \mathrm{~b}$ & $28.5 \mathrm{ab}$ & $4.3 \mathrm{ab}$ & $0.0 \mathrm{~b}$ & $5.3 \mathrm{~b}$ & $1.1 \mathrm{ab}$ & $0.4 \mathrm{a}$ & $10.7 b c$ & $6.4 \mathrm{abc}$ \\
\hline $\mathrm{NT}+\mathrm{B}$ & $5.5 \mathrm{~b}$ & $20.2 \mathrm{bc}$ & $3.1 \mathrm{~cd}$ & $0.0 \mathrm{~b}$ & $5.2 \mathrm{~b}$ & $0.7 \mathrm{ab}$ & $0.3 \mathrm{ab}$ & $9.3 \mathrm{c}$ & $5.2 b c$ \\
\hline Pasture & $6.4 \mathrm{a}$ & $9.7 \mathrm{~cd}$ & $2.5 \mathrm{~d}$ & $0.0 \mathrm{~b}$ & $2.0 \mathrm{c}$ & $0.6 \mathrm{~b}$ & $0.1 \mathrm{c}$ & $13.7 \mathrm{ab}$ & $7.4 \mathrm{ab}$ \\
\hline Native forest & $6.3 \mathrm{a}$ & $6.2 \mathrm{~d}$ & $2.2 \mathrm{~d}$ & $0.0 \mathrm{~b}$ & 7.9a & $0.9 \mathrm{ab}$ & $0.3 \mathrm{abc}$ & $16.7 \mathrm{a}$ & $8.3 \mathrm{a}$ \\
\hline $\mathrm{CV}(\%)$ & 4.3 & 31.3 & 16.9 & 26.4 & 26.0 & 31.3 & 32.5 & 17.0 & 21.5 \\
\hline
\end{tabular}


continuação

\begin{tabular}{|c|c|c|c|c|c|c|c|c|c|}
\hline & \multicolumn{9}{|c|}{$0.1-0.2 \mathrm{~m}$} \\
\hline $\mathrm{NT}_{6}$ & $5.3 b$ & $8.7 \mathrm{ab}$ & $3.2 \mathrm{~b}$ & $0.0 \mathrm{~b}$ & $3.3 \mathrm{bc}$ & $1.2 \mathrm{a}$ & $0.2 \mathrm{ab}$ & $5.2 \mathrm{c}$ & $6.4 \mathrm{~d}$ \\
\hline $\mathrm{NT}_{14}^{\circ}$ & $4.8 \mathrm{c}$ & $13.3 \mathrm{a}$ & $4.5 \mathrm{a}$ & $0.5 \mathrm{a}$ & $2.2 \mathrm{~cd}$ & $0.3 \mathrm{~cd}$ & $0.1 \mathrm{~b}$ & $6.6 \mathrm{c}$ & $7.8 \mathrm{~cd}$ \\
\hline $\mathrm{NT}_{22}{ }^{14}$ & $5.5 b$ & $10.0 \mathrm{ab}$ & $3.8 \mathrm{ab}$ & $0.0 \mathrm{~b}$ & $4.5 \mathrm{ab}$ & $0.8 \mathrm{~b}$ & $0.3 \mathrm{a}$ & $9.3 \mathrm{a}$ & $10.8 \mathrm{ab}$ \\
\hline $\mathrm{NT}+\mathrm{B}$ & $5.3 b$ & $10.2 \mathrm{ab}$ & $3.1 \mathrm{bc}$ & $0.0 \mathrm{~b}$ & $3.9 \mathrm{ab}$ & $0.6 \mathrm{c}$ & $0.2 \mathrm{ab}$ & $6.9 \mathrm{bc}$ & $8.3 \mathrm{bcd}$ \\
\hline Pasture & $6.4 \mathrm{a}$ & $8.4 \mathrm{ab}$ & $2.2 \mathrm{c}$ & $0.0 \mathrm{~b}$ & $1.6 \mathrm{~d}$ & $0.2 \mathrm{~d}$ & $0.1 \mathrm{~b}$ & $10.7 \mathrm{a}$ & $12.4 \mathrm{a}$ \\
\hline Native forest & $6.1 \mathrm{a}$ & $4.8 b$ & $2.2 \mathrm{c}$ & $0.0 \mathrm{~b}$ & $5.3 \mathrm{a}$ & $0.9 \mathrm{~b}$ & $0.2 \mathrm{ab}$ & $9.1 \mathrm{ab}$ & 10.2abc \\
\hline $\mathrm{CV}(\%)$ & 3.7 & 30.3 & 15.6 & 24.1 & 22.6 & 19.9 & 40.9 & 14.6 & 14.8 \\
\hline & \multicolumn{9}{|c|}{$0.2-0.4 \mathrm{~m}$} \\
\hline $\mathrm{NT}_{6}$ & $5.5 \mathrm{bc}$ & 7.9a & $2.8 \mathrm{ab}$ & $0.0 \mathrm{~b}$ & $3.7 \mathrm{a}$ & $1.0 \mathrm{a}$ & $0.1 b$ & $4.5 \mathrm{c}$ & $9.6 \mathrm{c}$ \\
\hline $\mathrm{NT}_{14}$ & $4.9 \mathrm{~d}$ & $6.0 \mathrm{a}$ & $3.8 \mathrm{a}$ & $0.3 \mathrm{a}$ & $2.3 \mathrm{bc}$ & $0.4 b c$ & $0.1 b$ & $5.1 b c$ & $10.9 b c$ \\
\hline $\mathrm{NT}_{22}$ & $5.5 b c$ & $6.6 \mathrm{a}$ & $2.7 \mathrm{ab}$ & $0.0 \mathrm{~b}$ & $4.2 \mathrm{a}$ & $0.8 \mathrm{ab}$ & $0.2 \mathrm{a}$ & $7.5 \mathrm{a}$ & $16.2 \mathrm{a}$ \\
\hline $\mathrm{NT}+\mathrm{B}$ & $5.4 \mathrm{c}$ & $5.8 \mathrm{a}$ & $2.7 \mathrm{ab}$ & $0.0 \mathrm{~b}$ & $3.3 \mathrm{ab}$ & $0.5 b c$ & $0.2 \mathrm{a}$ & $4.8 b c$ & $10.6 b c$ \\
\hline Pasture & $6.5 \mathrm{a}$ & $6.3 \mathrm{a}$ & $2.2 \mathrm{~b}$ & $0.0 \mathrm{~b}$ & $1.3 \mathrm{c}$ & $0.2 \mathrm{c}$ & $0.1 b$ & $7.3 \mathrm{a}$ & $16.0 \mathrm{a}$ \\
\hline Native forest & $5.9 b$ & $4.7 \mathrm{a}$ & $2.5 \mathrm{ab}$ & $0.0 \mathrm{~b}$ & $4.2 \mathrm{a}$ & $0.6 \mathrm{abc}$ & $0.2 \mathrm{a}$ & $6.8 \mathrm{ab}$ & $13.9 \mathrm{ab}$ \\
\hline $\mathrm{CV}(\%)$ & 4.1 & 29.6 & 24.7 & 22.5 & 18.4 & 37.7 & 40.7 & 17.5 & 14.3 \\
\hline
\end{tabular}

Values represented by the different letters in the column, for each soil depth show significant differences (Tukey test, $\mathrm{P} \leq 0.05$ ). Source: Elaboration of the authors.

For the $\mathrm{P}$ concentration in the soil, only in the 0.20-0.40 m layer were not verified differences in the levels in different management systems. In the 0-0.05 m soil layer, areas of $\mathrm{NT}_{22}$ and $\mathrm{NT}+\mathrm{B}$ showed upper values to the forest area. In the $0-0.05$ and 0.05-0.10 m layers were observed upper P levels, reaching $35.5 \mathrm{mg} \mathrm{dm}^{-3}$ in the area of $\mathrm{NT}_{14}$ compared with the area of native forest. These results may be attributed to phosphate fertilization performed annually in soybean crops in summer and maize and/or wheat in the fall-winter and low natural fertility of the soil in relation to $\mathrm{P}$ of the forested area. Dalchiavon et al. (2012) in areas of NT also reported higher phosphorus concentration in surface layers. For exchangeable bases, especially $\mathrm{Ca}^{2+}$, were observed higher levels in the area under forest vegetation, especially in the 0-0.05 and 0.05-0.10 m soil layers, reaching $8.6 \mathrm{cmol}_{\mathrm{c}} \mathrm{dm}^{-3}$ in the $0-0.05 \mathrm{~m}$ layer. Costa et al. (2007) obtained similar results on a Red Latosol of Mato Grosso do Sul, Brazil.

In general, higher $\mathrm{Mg}^{2+}$ levels were found in the area under $\mathrm{NT}_{6}$, although differences were not observed between the layers for the area under $\mathrm{NT}_{22}$, with values ranging from 1.0 to $1.8 \mathrm{cmol}_{\mathrm{c}} \mathrm{dm}^{-3}$ in the $0.20-0.40 \mathrm{~m}$ and $0-0.05$ layers, respectively.
For the $\mathrm{K}$, the only area of $\mathrm{NT}_{22}$ differed from forest area in the $0-0.05 \mathrm{~m}$ layer with $0.6 \mathrm{cmol}_{\mathrm{c}} \mathrm{dm}^{-3}$ concentration. Higher K levels in the soil permit that below potassium fertilizers rates may be applied in fertilizer, without adversely affecting crop yields (DALCHIAVON et al., 2012).

\section{Total soil organic carbon stock}

For TOC, there was tendency of increased levels due to the adoption time of no-till, however without differences for the first two layers, with values ranging from 7.8 to $15.6 \mathrm{~g} \mathrm{~kg}^{-1}$ in the 0.05 0.10 and $0-0.05$ soil layers for the $\mathrm{NT}_{6}$ and $\mathrm{NT}_{22}$, respectively (Table 4). The values presented here were lower than those reported by Souza and Alves (2003) in tropical soil of Mato Grosso do Sul, and by Guareschi; Pereira and Perin (2012a) in soil of Goiás, respectively with 8 and 3 years of first adoption of no-till, and Boddey et al. (2010) in soils of southern Brazil. Assessing the same crop rotation systems in southern Brazil, Sisti et al. (2004) did not find significant accumulations of TOC in the 0-0.30 $\mathrm{m}$ soil layer after 13 years under NT. In general, higher levels of TOC were verified for areas of 
forest, pasture and $\mathrm{NT}_{22}$, however similar values to each other in the $0.10-0.20$ and $0.20-0.40 \mathrm{~m}$ layers. For the $0-0.05 \mathrm{~m}$ layer, the area under forest had a level of $30.5 \mathrm{~g} \mathrm{~kg}^{-1} \mathrm{TOC}$, differing from the managed areas.

The lower TOC levels were verified in depth for the studied areas, confirming the results reported by Guareschi, Pereira and Perin (2012b) with the same soil type and crop rotation system (i.e., soybean in the summer and maize in winter) in areas under 3, 15 and 20 years of first adoption of no-till in the Goiás, Brazil. The decreased $\mathrm{C}$ levels in depth shows the contribution of the $\mathrm{C}$ inputs in the soil surface layer compared to the $0.05-0.10 \mathrm{~m}, 0.10-0.20$ and 0.20 $0.40 \mathrm{~m}$ layers. Expected results for systems without intensive soil tillage, as consolidated no-till.

The contribution of plant residues of crops for SOM was poor, because climate conditions favored the rapid decomposition of crop residues. This indicates the importance of the crop uses with higher $\mathrm{C} / \mathrm{N}$ ratio to promote the formation of straw, which explains the results of the difference absence for the TOC levels in the upper layers of areas with different adoption times of the NT (Table 3). These results also reported by Paul et al. (2013) after four years of soybean-maize succession. Some recent studies have questioned whether the NT provides increased soil TOC stocks (BLANCO-CANQUI; LAL, 2008; CHRISTOPHER; LAL; MISHRA, 2009), because this increase also depends on the heterogeneity of crops installed in the area. The low values may be explained by the low $\mathrm{C}$ input coming from the management used in agricultural production (OGLE; SWAN; PAUSTIAN, 2012). For Brazilian tropical conditions in areas under NT for 20 years Oliveira et al. (2004) found higher accumulation of SOM in the soil surface layers in the soybean, maize and rice crops.
The highest values of total soil organic carbon (TOC) stocks were found in the forested area in the 0-0.05 m layer, differing from the managed areas, with value of $12.5 \mathrm{Mg} \mathrm{ha}^{-1}$ (Table 4). For the other layers, there are similar values in the areas under $\mathrm{NT}_{22}$, pasture and forest. For the top two layers, the TOC stocks values increased with adoption time of the NT; however, there was no significant difference in the area under $\mathrm{NT}_{22}$ in the two layers, with a maximum value of $6.4 \mathrm{Mg} \mathrm{ha}^{-1}$. These values were lower than those found by Guareschi, Pereira and Perin (2012a, 2012b), which used the same crop rotation systems, ranging of 3 to 20 years of cultivation under NT in the Brazilian tropical soils and Boddey et al. (2010) in southern Brazil with 17 years of succession under NT.

For the last two layers, there was tendency of increase of TOC stocks in the area under $\mathrm{NT}+\mathrm{B}$, however not differing areas of $\mathrm{NT}_{6}$ and $\mathrm{NT}_{14}$. This demonstrates that, for the condition studied, after four years of no-till with integration of maize + ruzigrass (Brachiaria ruziziensis), the $\mathrm{C}$ amount from of ruzigrass straw were not sufficient to raise the TOC stocks in relation to the areas of soybean and maize or wheat succession, although there are differences in the amount of dry matter (DM) after maize cultivation. The amount of $\mathrm{DM}$ of $\mathrm{NT}+\mathrm{N}$ system was $9.58 \mathrm{Mg} \mathrm{ha}^{-1}$, while areas in soybean and maize or wheat succession ranged from 5.87 to $6.63 \mathrm{Mg} \mathrm{ha}^{-1}$, being different from each other (Figure $3)$. Proper management of integration systems can benefit the $\mathrm{C}$ inputs in the system and consequently increase the TOC stocks and soil fertility (BELL; MOORE, 2012), since the amount of crop residue that enters the system influences the addition rate of $\mathrm{C}$ to the soil (JOHNSTON; POULTON; COLEMAN, 2009). The magnitude of this process depends of the amount and quality of crop residues added to the soil surface (PAUL et al., 2013). 
Figure 3. Amount of dry matter (DM) on the surface of the soil after winter season of 2012 under management systems with different deployment times and area of native forest in the western region of Paraná, Brazil.

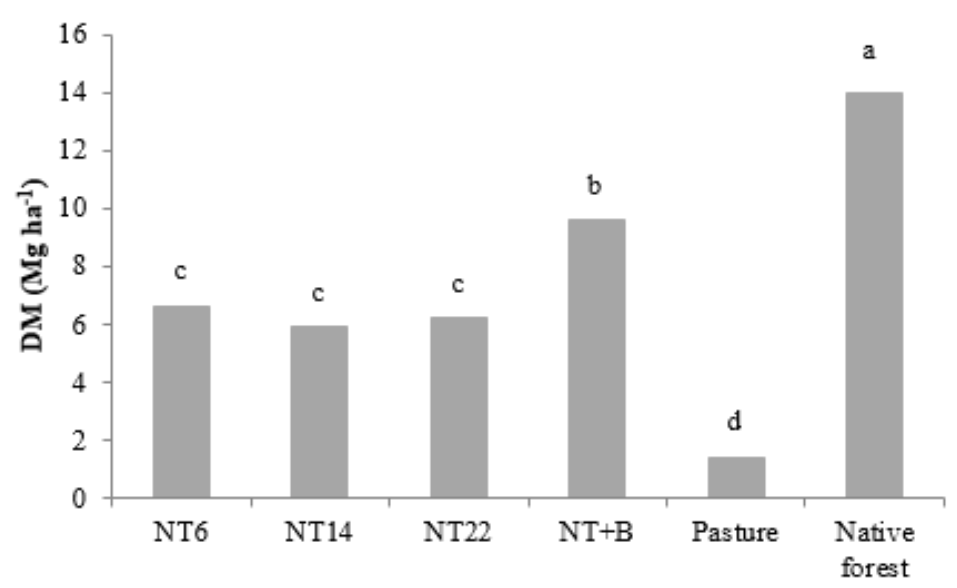

Source: Elaboration of the authors.

Changes in the vegetation and management practices may influence the TOC stock; they may change the input and loss rates of SOM (PLAZABONILLA; CANTERO-MARTÍNEZ; ÁLVAROFUENTES, 2010). Changes in management systems have direct effect on the soil $\mathrm{C}$ balance. There was marked decrease in TOC stock in the surface soil layers, especially in the 0-0.05 m layer in relation to the forest area (Figure 4), indicating greater susceptibility of TOC oxidation in this soil layer under determined management systems. Even in management systems with high amount inputs of crop residue on the soil surface, in tropical regions it is difficult to increase the TOC levels and stocks, i.e. return to the levels of the areas under natural vegetation (BLAIR, 2000). This negative variation on TOC stock in the $0-0.05 \mathrm{~m}$ soil layer is most evident in areas under $\mathrm{NT}_{6}$ (Figure 4a), $\mathrm{NT}_{14}$ (Figure $4 \mathrm{~b}$ ) and NT+B (Figure 4d), followed by areas under $\mathrm{NT}_{22}$ (Figure 4c) and pasture (Figure 4e). Virto et al. (2011) showed that the variation of TOC stocks could be positive or negative depending of $\mathrm{C}$ inputs in the agricultural production system. Paul et al. (2013) report that future studies should establish for different climatic regions and soil types, retention levels of minimum residues critical for the OC maintenance and soil conservation.
Negative variations of TOC stocks were observed in relation to the area of native forest for all layers evaluated in the areas of $\mathrm{NT}_{6}$ (Figure 4a), $\mathrm{NT}_{14}$ (Figure $4 \mathrm{~b}$ ) and $\mathrm{NT}+\mathrm{B}$ (Figure $4 \mathrm{~d}$ ). In turn, only in the $0.10-0.20$ and $0.20-0.40 \mathrm{~m}$ layers, areas under $\mathrm{NT}_{22}$ (Figure 4c) and pasture (Figure 4e) showed positive change in TOC stock. In no-till, was not confirmed its potential for sequestering $\mathrm{C}$ as reported by Corazza et al. (1999). In this system, a more effective management of plant residues on the soil surface, and a crop rotation system more diverse can contribute to enhance the growth of deep roots and facilitate the $\mathrm{C}$ accumulation in the profile. This supports the hypothesis that the characteristics of crop rotation systems can determine the appropriate management systems, particularly for the C sequestration (D'ANDRÉA et al., 2004). These results were evident in the work of Sisti et al. (2004); Boddey et al. (2010) in southern Brazil, when using common vetch as a cover crop in the production system. The increasing complexity of rotation, depending on the region and soil type, can sequester around $200 \mathrm{~kg} \mathrm{C} \mathrm{ha}{ }^{-1} \mathrm{yr}^{-1}$ (WEST; POST, 2002). 


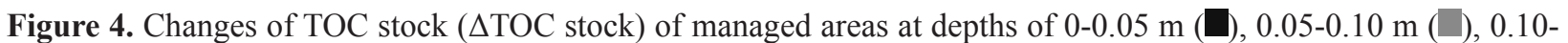
$0.20 \mathrm{~m}(\square)$ and $0.20-0.40 \mathrm{~m}(\square)$ in relation to the area of native forest in the western region of Paraná, Brazil, in 2012. $\mathrm{NT}_{6}$ : no-till for 6 years (a), $\mathrm{NT}_{14}$ : no-till for 14 years (b), $\mathrm{NT}_{22}$ : no-till for 22 years (c), NT+B: no-till with integration of maize + ruzigrass (Brachiaria ruziziensis) (d), pasture (e) and soil profile of 0-0.40 $\mathrm{m}$ (f).

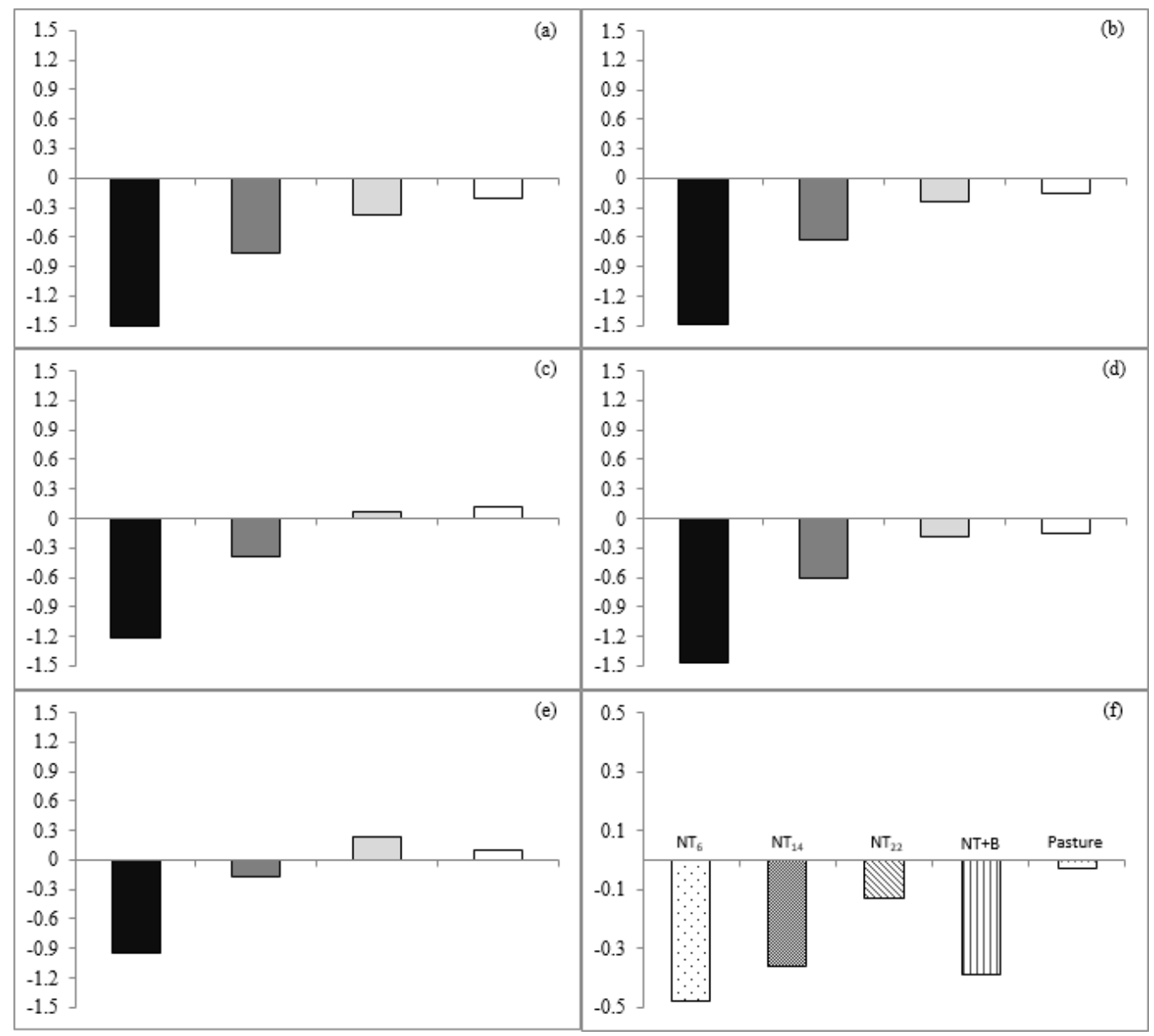

Source: Elaboration of the authors.

For pasture, negative change of TOC stock was observed in the first two layers (Figure 4e), however smaller than the other areas evaluated, mainly due to the contribution of pasture root system to accumulate $\mathrm{C}$, as reported by Acharya, Rasmussen and Eriksen (2012), once the study area is occupied with permanent pasture for 39 years. For the Cerrado region, D'Andrea et al. (2004) observed positive change in the TOC stock in areas of permanent pasture with tropical grasses of the genus Brachiaria, mainly due to the continuous renewal of the root system, unlike what occurs in areas of degraded pastures. Increase of $\mathrm{CO}_{2}$ emissions in degraded pastures have been reported compared with cultivated pastures (PLANT et al., 2011), being variable from region to region, as well as influenced by the $\mathrm{C}$ amount inputs in the production system, decomposition rate, soil texture (JOHNSTON, POULTON; COLEMAN, 2009), soil mineralogical composition and climate condition (WANG et al., 2010).

When analyzing the soil profile (Figure 4f) there was tendency decrease the negative values of TOC stocks in relation to forest area as a function of adoption time of the NT. Area under NT $+\mathrm{B}$ showed a negative change similar to the $\mathrm{NT}_{14}$ area. Different management practices, including the integration 
of grasses and legumes, improved of pasture, notill and crop rotation can increase the TOC stock (HUTCHINSON; CAMPBELL; DESJARDINS, 2007).

The stratification index (SI) proposed by Franzluebbers (2002) was calculated in relation to TOC levels of 0-0.05 layer and the 0.10-0.20 m layer (arable layer). There was variation between 1.73 and 3.43 for the SI values in the $\mathrm{NT}_{22}$ and forest areas, respectively (Figure 5). Other studies have shown that the SI value can vary from 1.10 to 1.90 for conventional management systems and 2.10 to 4.10 for no-till system (FRANZLUEBBERS, 2002). Considering only managed areas, the SI values were increasing in the following order: 1.73 $\left(\mathrm{NT}_{22}\right), 1.78$ (pasture), $1.82(\mathrm{NT}+\mathrm{B}), 1.91\left(\mathrm{NT}_{14}\right)$ and $2.34\left(\mathrm{NT}_{6}\right)$. Tormena et al. (2004) studied areas with nine years of cultivation under rotation (maize/ wheat/soybean/oat black/soybean/forage turnip) and crop succession (soybean/maize or wheat) in a Red Latosol of the Paraná; and found SI values of 1.73 and 1.28 to these areas, respectively, i.e., highest SI in the rotation system.

There is tendency of reduction in the SI values with the adoption time of the NT, and this is due to the $\mathrm{C}$ accumulation in the $0-0.05 \mathrm{~m}$ layer not be significant with the passage of the succession cultivations of soybean in the summer and maize or winter wheat, as can be seen in Table 4. There is no difference in TOC levels between areas under $\mathrm{NT}_{6}, \mathrm{NT}_{14}$ and $\mathrm{NT}_{22}$ in the 0-0.05 and 0.05-0.10 m layers. In the area under forest, there was higher SI value (i.e., 3.43), indicating that occurred higher $\mathrm{C}$ accumulation in surface. Under cerrado vegetation, Salton (2005) observed SI value of 3.05 and the author pointed out that the use of this indicator has as an advantage the facility of obtaining its value depends only on TOC values for two soil layers, is not necessary the use of a reference area. Although there are no differences between areas managed, there was some degree of $\mathrm{C}$ stratification in depth, with values greater than one.

Figure 5. Stratification index (SI) of total organic carbon of soils under management systems with different deployment times and area of native forest in the western region of Paraná, Brazil, in 2012.

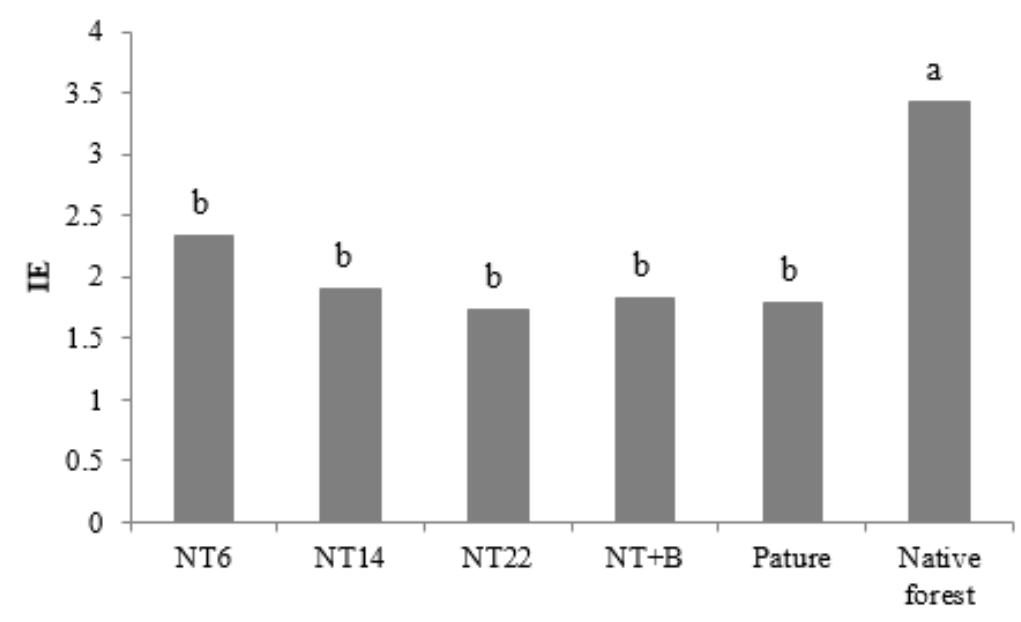

Source: Elaboration of the authors.

In the canonical analysis of physical and chemical properties and TOC stocks, the first and second canonical variable were 71.4 and $21.6 \%$ of the total variation, respectively, representing $93 \%$ of total variation, reaching the minimum requirements for evaluation by graphic dispersion 
(CROSS; REGAZZI, 1994). Besides of the graphic dispersion, the grouping method of Tocher modified was used, showing the formation of two groups: the first formed by native forest area and the second group of the managed areas under $\mathrm{NT}_{6}, \mathrm{NT}_{14}, \mathrm{NT}_{22}$ $\mathrm{NT}+\mathrm{B}$ and pasture (Figure 6). These results show that management systems with different deployment times showed a similar standard when considering the physical and chemical properties and soil $\mathrm{C}$ stocks.

The variables of less importance, for having greater weighting coefficient in the last canonical variables are the sand and silt contents and soil particle density (PD) for the physical properties and potential acidity and calcium level for chemical properties. Carneiro et al. (2009) showed in a test grouping for two soil types, which in both the physical properties were contributed the least to discriminate the evaluated management systems.
With respect to the area of forest, the management systems caused reductions in several properties studied, which can lead to soil degradation over time, as reported also by Carneiro et al. (2009) in different management systems under Latosol and Neosol of the tropical region.

In general, there was equal conditions for all managed areas, which suggests that the management systems, especially areas with different adoption times of the NT in the crop succession system (soybean and maize or wheat), have little effect on the improvement of the soil properties compared with the area of native forest. The forest is a reference area for quality assessment of agricultural production systems. This may be due mainly by the absence of a system of crop rotation, involving a larger number of plant species, both in quantity and in quality, as well as different capacities to exploitation of their root system in depth.

Figure 6. Dispersion of different use and management systems of soils and grouping by the Tocher modified method from the first two canonical variables in an Eutroferric Red Latosol under management systems with different deployment times in the western region of Paraná, Brazil, in 2012.

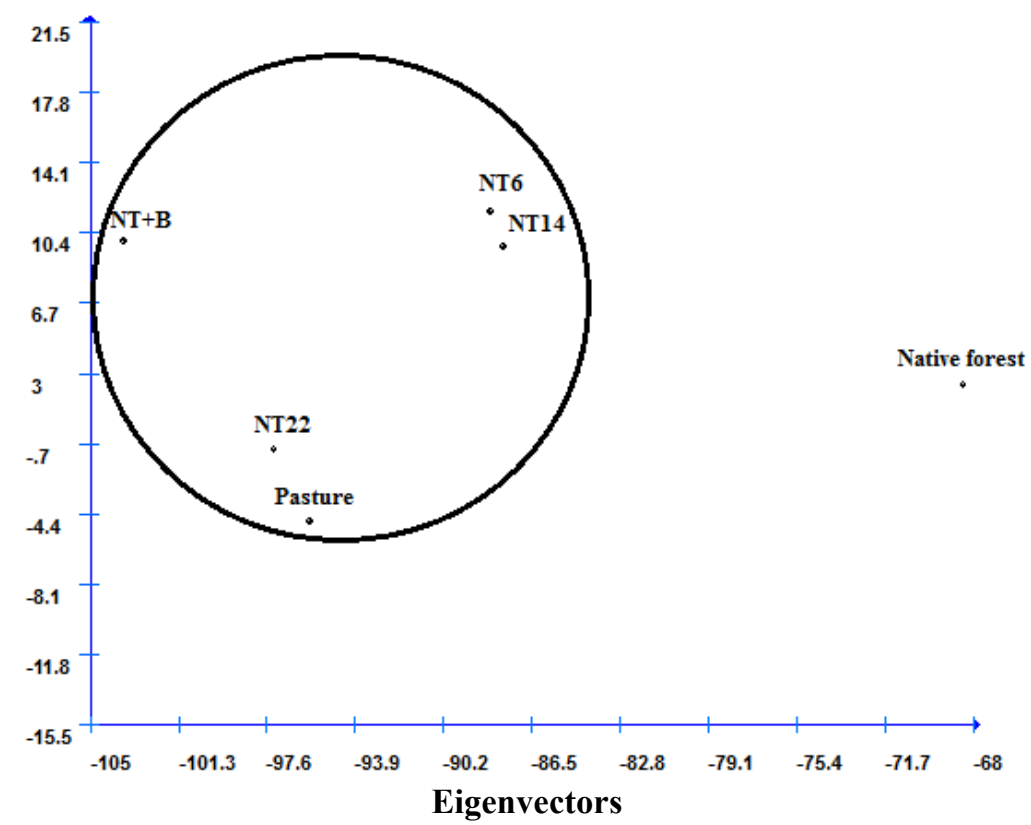

Source: Elaboration of the authors. 


\section{Conclusions}

In the managed areas, there was the presence of compacted subsurface layers, as reported by the highest values of soil bulk density and penetration resistance.

The soybean/maize or wheat succession systems under no-till does not contribute effectively to the increase of total soil organic carbon stocks, regardless of the deployment times of no-till.

There was negative change on total soil organic carbon stocks in the managed areas compared to native forest, mainly in the superficial soil layers.

Different management systems under long-term of no-till are not grouped with the native forest area, reference area, to consider all the physical and chemical properties, and organic carbon stocks.

\section{Acknowledgments}

To farmers by the availability of areas for the study.

To CAPES (Coordination for the Improvement of Higher Education Personnel), for providing scholarship to the authors.

To CNPq (National Council for Scientific and Technological Development), for financial support (Chamada Universal - MCTI/CNPQ N ${ }^{\circ}$ 14/2012) and award for excellence in research to the authors.

\section{References}

ACHARYA, B. S.; RASMUSSEN, J.; ERIKSEN, J. Grassland carbon sequestration and emissions following cultivation in a mixed crop rotation. Agriculture, Ecosystems \& Environment, Amsterdam, v. 153, n. 15, p. 33-39, 2012.

ÁlVARO-FUENTES, J.; EASTER, M.; PAUSTIAN, K. Climate change effects on organic carbon storage in agricultural soils of northeastern Spain. Agriculture, Ecosystems \& Environment, Amsterdam, v. 155, n. 15, p. 87-94, 2012.

ANGHINONI, I. Fertilidade do solo e seu manejo no sistema plantio direto. In: NOVAIS, R. F.; ALVAREZ, V.
H.; BARROS, N. F.; FONTES, R. L. F.; CANTARUTTI, R. B.; NEVES, J. C. L. Fertilidade do solo. Viçosa: SBCS, 2007. p. 873-928.

BARBOSA FILHO, M. P.; FAGERIA, N. K.; ZIMMERMANN, F. J. P. Atributos de fertilidade do solo e produtividade do feijoeiro e da soja influenciados pela calagem em superfície e incorporada. Ciência e Agrotecnologia, Lavras, v. 29, n. 3, p. 507-514, 2005.

BARROS, N. F.; COMERFORD, N. B. Sustentabilidade da produção de florestas plantadas na região tropical. In: ALVAREZ, V. H.; SCHAEFER, C. E. G. R.; BARROS, N. F.; MELlO, J. W. V.; COSTA, L. M. Tópicos em ciência do solo. (Ed.). Viçosa: SBCS, 2002. p. 487-592.

BRADY, N. C.; BUCKMAN, H. O. Natureza e propriedades dos solos. 6. ed. Rio de Janeiro: Freitas Bastos, 1983, $647 \mathrm{p}$.

BELL, L. W.; MOORE, A. D. Integrated crop-livestock systems in Australian agriculture: trends, drivers and implications. Agricultural Systems, Amsterdam, v. 111, n. 7, p. 1-12, 2012.

BERNOUX, M.; FEIGL, B. J.; CERRI, C. C.; GERALDES, A. P. A.; FERNANDES, S. A. P. Carbono e nitrogênio em solo de uma cronossequência de floresta tropical - pastagem de Paragominas. Scientia Agrícola, Piracicaba, v. 56, n. 4, p. 1-11, 1999.

BERTOL, I.; ALBUQUERQUE, J. A.; LEITE, D.; AMARAL, A. J.; ZOLDAN JUNIOR, W. A. Propriedades físicas do solo sob preparo convencional e semeadura direta em rotação e sucessão de culturas, comparadas às do campo nativo. Revista Brasileira de Ciência do Solo, Viçosa, v. 28, n. 1, p. 155-165, 2004.

BERTOL, I.; BEUTLER, J. F.; LEITE, D.; BATISTELA, O. Propriedades físicas de um Cambissolo Húmico afetadas pelo tipo de manejo do solo. Scientia Agricola, Piracicaba, v. 58, n. 3, p. 555-560, 2001.

BEUTLER, A. N.; CENTURION, J. F. Compactação do solo no desenvolvimento radicular e na produtividade da soja. Pesquisa Agropecuária Brasileira, Brasília, v. 39, n. 6, p. 581-588, 2004.

BLAIR, N. Impact of cultivation and sugar-cane green trash management on carbon fractions and aggregate stability for a Chromic Luvisol in Queensland, Australia. Soil \& Tillage Research, Amsterdam, v. 55, n. 1, p. 183191, 2000.

BLANCO-CANQUI, H.; LAL, R. No-tillage and soilprofile carbon sequestration: an on-farm assessment. Soil Science Society of America Journal, Madison, v. 72, n. 3, p. 693-701, 2008. 
BODDEY, R. M.; JANTALIA, C. P.; CONCEICÃO, P. C.; ZANATTA, J. A.; BAYER, C.; MIELNICZUK, J.; DIECKOW, J.; SANTOS, H. P.; DENARDIN, J. E.; AITA, C.; GIACOMINI, S. J.; ALVES, B. J. R.; URQUIAGA S. Carbon accumulation at depth in Ferralsols under zero-till subtropical agriculture. Global Change Biology, Illinois, v. 16, n. 2, p. 784-795, 2010.

CARNEIRO, M. A. C.; SOUZA, E. D.; REIS, E. F.; PEREIRA, H. S.; AZEVEDO, W. R. Atributos físicos, químicos e biológicos de solo de cerrado sob diferentes sistemas de uso e manejo. Revista Brasileira de Ciência do Solo, Viçosa. v. 33, n. 1, p. 147-157, 2009.

CARTER, M. R. Soil quality for sustainable land management: Organic matter and aggregation interactions that maintain soil functions. Agronomy Journal, Madison, v. 94, n. 1, p. 38-47, 2002.

CAVIGLIONE, J. H.; KIIHL, L. R. B.; CARAMORI, P. H.; OlIVEIRA, D. Cartas climáticas do Paraná. Londrina : IAPAR, 2000. CD-ROM.

CERRI, C. C.; GALDOS, M. V.; MAIA, S. M. F.; BERNOUX, M.; FEIGL, B. J.; POWLSON, D.; CERRI, C. E. P. Effect of sugarcane harvesting systems on soil carbon stocks in Brazil: an examination of existing data. European Journal of Soil Science, Oxford, v. 62, n. 1, p. 23-28, 2011.

CHRISTOPHER, S. F.; LAL, R.; MISHRA, U. Regional study of no-till effects on carbon sequestration in the midwestern United States. Soil Science Society of America Journal, Madison, v. 73, n. 1, p. 207-216, 2009.

CORAZZA, E. J.; SILVA, J. E.; RESCK, D. V. S.; GOMES, A. C. Comportamento de diferentes sistemas de manejo como fonte ou depósito de carbono em relação à vegetação de cerrado. Revista Brasileira de Ciência do Solo, Viçosa, v. 23, n. 2, p. 425-432, 1999.

COSTA, M. J.; ROSA JUNIOR, E. J.; ROSA, Y. B. C. J.; SOUZA, L. C. F.; ROSA, C. B. J. Atributos químicos e físicos de um latossolo sendo influenciados pelo manejo do solo e efeito da gessagem. Acta Scientiarum: Agronomy, Maringá, v. 29, p. 701-708, 2007. Suplemento.

CRUZ, C. D. Programa genes: biometria. Viçosa: UFV, 2006. 382 p.

CRUZ, C. D.; REGAZZI, A. J. Modelos biométricos aplicados ao melhoramento genético. Viçosa: UFV, $1994.394 \mathrm{p}$.

DALCHIAVON, F. C.; CARVALHO, M. P.; ANDREOTTI, M.; MONTANARI, R. Variabilidade espacial de atributos da fertilidade de um Latossolo Vermelho Distroférrico sob sistema plantio direto. Revista Ciência Agronômica, Fortaleza, v. 43, n. 3, p. 453-461, 2012.
D'ANDRÉA, A. F.; SILVA, M. L. N.; CURI, N.; GUILHERME, L. R. G. Estoque de carbono e nitrogênio e formas de nitrogênio mineral em um solo submetido a diferentes sistemas de manejo. Pesquisa Agropecuária Brasileira, Brasília, v. 39, n. 2, p. 179-186, 2004.

DIMASSI, B.; COHANB, J. P.; LABREUCHE, J.; MARY, B. Changes in soil carbon and nitrogen following tillage conversion in a long-term experiment in Northern France. Agriculture, Ecosystems \& Environment, Amsterdam, v. 169, n. 1, p. 12-20, 2013.

ELLERT, B. H.; BETTANY, J. R. Calculation of organic matter and nutrients stored in soils under contrasting management regimes. Canadian Journal Soil Science, Ottawa, v. 75, n. 4, p. 529-538, 1995.

EMPRESA BRASILEIRA DE PESQUISA AGROPECUÁRIA - EMBRAPA. Manual de métodos de análises de solo. 2. ed. Rio de Janeiro: Embrapa, 1997. $212 \mathrm{p}$.

Mapa de solos do estado do Paraná. Rio de Janeiro: Embrapa, 2007. 73 p.

. Manual de análises químicas de solos, plantas e fertilizantes. 2. ed. Brasília: Embrapa, 2009. 628 p.

Sistema brasileiro de classificação de solos. 3 . ed. Brasília: Embrapa, 2013. 353 p.

FERRERAS, L. A.; COSTA, J. L.; GARCIA, F. O.; PECORARI, C. Effects of no tillage on some soil physical properties of a structural degraded Petrocalcic Paleudoll of the southern "Pampa" of Argentina. Soil \& Tillage Research, Amsterdam, v. 54, n. 1-2, p. 31-39, 2000.

FRANZLUEBBERS, A. J. Soil organic matter stratification ratio as an indicator of soil quality. Soil \& Tillage Research, Amsterdam, v. 66, n. 2, p. 95-106, 2002.

FRAZÃO, L. A.; SANTANA, I. K. S.; CAMPOS, D. V. B.; FEIGL, B. J.; CERRI, C. C. Estoques de carbono e nitrogênio e fração leve da matéria orgânica em Neossolo Quartzarênico sob uso agrícola. Pesquisa Agropecuária Brasileira, Brasília, v. 45, n. 10, p. 1198-1204, 2010.

GUARESCHI, R. F.; PEREIRA, M. G.; PERIN, A. Estoque de carbono em Latossolo vermelho distroférrico sob diferentes sistemas de manejo. Agrária, Recife, v. 7, n. 4, p. 597-802, 2012a.

Deposição de resíduos vegetais, matéria orgânica leve, estoques de carbono e nitrogênio e fósforo remanescente sob diferentes sistemas de manejo no cerrado goiano. Revista Brasileira de Ciência do Solo, Viçosa, v. 36, n. 3, p. 909-920, 2012 b. 
HUTCHINSON, J. J.; CAMPBELL, C. A.; DESJARDINS, R. L. Some perspectives on carbon sequestration in agriculture. Agricultural and Forest Meteorology, Amsterdam, v. 142, n. 2-4, p. 288-302, 2007.

JOHNSTON, A. E.; POULTON, P. R.; COLEMAN, K. Soil organic matter: its importance in sustainable agriculture and carbon dioxide fluxes. Advances in Agronomy, Amsterdam, v. 101, n. 1, p. 1-57, 2009.

KRAGT, M. E.; PANNELL, D. J.; ROBERTSON, M. J.; THAMO, T. Assessing costs of soil carbon sequestration by crop-livestock farmers in Western Australia. Agricultural Systems, Amsterdam, v. 112, p. 27-37, 2012.

LOURENTE, E. R. P.; MERCANTE, F. M.; ALOVISI, A. M. T.; GOMES, C. F.; GASPARINI, A. S.; NUNES, C. M. Atributos microbiológicos, químicos e físicos de solo sob diferentes sistemas de manejo e condições de cerrado. Pesquisa Agropecuária Tropical, Goiânia, v. 41, n. 1, p. 20-28, 2011.

MARCOLAN, A. L.; ANGHINONI, I. Atributos físicos de um Argissolo e rendimento de culturas de acordo com o revolvimento do solo em plantio direto. Revista Brasileira de Ciência do Solo, Viçosa, v. 30, n. 1, p. 163$170,2006$.

MARRIOTT, E. E.; WANDER, M. M. Total and labile soil organic matter in organic and conventional farming systems. Soil Science Society of America Journal, Madison, v. 70, n. 3, p. 950-959, 2006.

OGLE, S. M.; SWAN, A.; PAUSTIAN, K. No-till management impacts on crop productivity, carbon input and soil carbon sequestration. Agriculture, Ecosystems and Environment, Amsterdam, v. 149, n. 1, p. 37-49, 2012.

OLIVEIRA, G. C.; DIAS JUNIOR, M. S.; RESCK, D. V. S.; CURI, N. Caracterização química e físico-hídrica de um Latossolo Vermelho após vinte anos de manejo e cultivo do solo. Revista Brasileira de Ciência do Solo, Viçosa, v. 28, n. 2, p. 327-336, 2004.

PAUL, B. K.; VANLAUWE, B.; AYUKE, F.; GASSNER, A.; HOOGMOED, M.; HURISSO, T. T.; KOALA, S.; LELEI, D.; NDABAMENYE, T.; SIX, J.; PULLEMAN, M. M. Medium-term impact of tillage and residue management on soil aggregate stability, soil carbon and crop productivity. Agriculture, Ecosystems \& Environment, Amsterdam, v. 164, n. 1, p. 14-22, 2013.

PLANTE, A. F.; FERNÁNDEZ, J. M.; HADDIX, M. L.; STEINWEG, J. M.; CONANT, R. T. Biological, chemical and thermal indices of soil organic matter stability in four grassland soils. Soil Biology \& Biochemistry, Amsterdam, v. 43, n. 5, p. 1051-1058, 2011.
PLAZA-BONILLA, D.; CANTERO-MARTÍNEZ, C.; ÁLVARO-FUENTES, J. Tillage effects on soil aggregation and soil organic carbon profile distribution under Mediterranean semi-arid conditions. Soil Use Management, Oxford, v. 26, n. 4, p. 465-474, 2010.

QUINCKE, J. A.; WORTMANN, C. S.; MAMO, M.; FRANTI, T.; DRIJBER, R. A. Occasional tillage of notill systems: carbon dioxide flux and changes in total and labile soil organic carbon. Agronomy Journal, Madison, v. 99, n. 4, p. 1158-1168, 2007.

SALTON, J. C. Matéria orgânica e agregação do solo na rotação lavoura-pastagem em ambiente tropical. 2008. (Tese de Doutorado em Ciência do Solo) - Universidade Federal do Rio Grande do Sul, Porto Alegre.

SILVA, R. H.; ROSOLEM, C. A. Crescimento radicular de espécies utilizadas como cobertura decorrente da compactação do solo. Revista Brasileira de Ciência do Solo, Viçosa, v. 25, n. 2, p. 253-260, 2001.

SISTI, C. P. J.; SANTOS, H. P.; KOHHANN, R.; ALVES, B. J. R.; URQUIAGA, S.; BODDEY, R. M. Change in carbon and nitrogen stocks under 13 years of conventional or zero tillage in southern Brazil. Soil \& Tillage Research, Amsterdam, v. 76, n. 1, p. 39-58, 2004.

SOUZA, Z. M.; ALVES, M. C. Propriedades químicas de um Latossolo Vermelho distroférrico de cerrado sob diferentes usos e manejos. Revista Brasileira de Ciência do Solo, Viçosa, v. 27, n. 1, p. 133-139, 2003.

STONE, L. F.; SILVEIRA, P. M. Efeitos do sistema de preparo e da rotação de culturas na porosidade e densidade do solo. Revista Brasileira de Ciência do Solo, Viçosa, v. 25, n. 2, p. 395-401, 2001.

TAYLOR, S. A.; ASHCROFT, G. L. Physical edaphology: the physics of irrigated and non-irrigated soils. San Francisco: W.H. Freeman, 1972. 532 p.

TORMENA, C. A.; FRIEDRICH, R.; PINTRO, J. C.; COSTA, A. C. S.; FIDALSKI, J. Propriedades físicas e taxa de estratificação de carbono orgânico num Latossolo vermelho após dez anos sob dois sistemas de manejo. Revista Brasileira de Ciência do Solo, Viçosa, v. 28, n. 6 , p. 1023-1031, 2004.

TORMENA, C. A.; ROlOFF, G.; SÁ, J. C. M. Propriedades físicas do solo sob plantio direto influenciadas por calagem, preparo inicial e tráfego. Revista Brasileira de Ciência do Solo, Viçosa, v. 22, n. 4, p. 301-309, 1998.

TORRES, J. L. R.; FABIAN, A. J.; PEREIRA, M. G. Alterações dos atributos físicos de um Latossolo vermelho submetido a diferentes sistemas de manejo. Ciência e Agrotecnologia, Lavras, v. 35, n. 3, p. 437-445, 2011. 
UMAKANT, M.; USSIRI, D.; LAL, R. Tillage effects on soil organic carbon storage and dynamics in Corn Belt of Ohio USA. Soil \&Tillage Research, Amsterdam, v. 107, n. 2, p. 88-96, 2010.

VIANA, E. T.; BATISTA, M. A.; TORMENA, C. A.; COSTA, A. C. S.; INOUE, T. T. Atributos físicos e carbono orgânico em Latossolo vermelho sob diferentes sistemas de uso e manejo. Revista Brasileira de Ciência do Solo, Viçosa, v. 35, n. 6, p. 2105-2114, 2011.

VIRTO, I.; BARRÉ, P.; BURLOT, A.; CHENU, C. Carbon input differences as the main factor explaining the variability in soil organic $C$ storage in no-tilled compared to inversion tilled agrosystems. Biogeochemistry, Coverage, v. 108, n. 1-3, p. 17-26, 2011.
WANG, Y.; FU, B.; LÜ, Y.; SONG, C.; LUAN, Y. Local-scale spatial variability of soil organic carbon and its stock in the hilly area of the Loess Plateau, China. Quaternary Research, Amsterdam, v. 73, n. 1, p. 70-76, 2010.

WEST, T. O.; POST, W. M. Soil organic carbon sequestration rates by tillage and crop rotation: a global data analysis. Soil Science Society of America Journal, Madison, v. 66, n. 6, p. 1930-1946, 2002. 